NBER WORKING PAPER SERIES

\title{
AROUND THE EUROPEAN PERIPHERY 1870-1913: GLOBALIZATION, SCHOOLING AND GROWTH
}

Kevin H. O'Rourke

Jeffrey G. Williamson

Working Paper 5392

\author{
NATIONAL BUREAU OF ECONOMIC RESEARCH \\ 1050 Massachusetts Avenue \\ Cambridge, MA 02138 \\ December 1995
}

Paper to be presented to the Congress of the European Association of Historical Economics, Universitá Cá Foscari di Venezia, Venice, Italy (January 19-20, 1996). This paper extends the arguments and evidence offered for Scandinavia in two of our papers in the Scandinavian Economic History Review: "Open Economy Forces and Late 19th Century Swedish Catch-Up: A Quantitative Accounting" 43, 2 (1995), pp. 171-203 and "Education, Globalization and CatchUp: Scandinavia in the Swedish Mirror" (forthcoming 1996). We are grateful for the excellent research assistance of Bill Collins and Josh Greenfield; and to Giovanni Federico, Pedro Lains, Leandro Prados and Jaime Reis for their generous assistance. Comments invited. This paper is part of NBER's research program in the Development of the American Economy. Any opinions expressed are those of the authors and not those of the National Bureau of Economic Research.

(C) 1995 by Kevin H. O'Rourke and Jeffrey G. Williamson. All rights reserved. Short sections of text, not to exceed two paragraphs, may be quoted without explicit permission provided that full credit, including $\odot$ notice, is given to the source. 


\section{AROUND THE EUROPEAN PERIPHERY \\ 1870-1913: GLOBALIZATION, SCHOOLING AND GROWTH}

\section{ABSTRACT}

On average, the poor European periphery converged on the rich industrial core in the four or five decades prior to World War I. Some, like the three Scandinavian economies, used industrialization to achieve a spectacular convergence on the leaders, especially in real wages and living standards. Some, like Ireland, seemed to do it without industrialization. Some, like Italy, underwent less spectacular catch-up, and it was limited to the industrializing North. Some, like Iberia, actually fell back. What accounts for this variety? What role did trade and tariff policy play? What about emigration and capital flows? What about schooling? We offer a tentative assessment of these contending explanations and conclude that globalization was by far the dominant force accounting for convergence (and divergence) around the periphery. Some exploited it well, and some badly.

Kevin H. O'Rourke Department of Political Economy University College Belfield, Dublin 4 IRELAND
Jeffrey G. Williamson Department of Economics 216 Littauer Center Harvard University Cambridge, MA 02138 and NBER 


\section{CENTER AND PERIPHERY: THE ARGUNENTS}

Does globalization produce convergence, or does it widen the gaps between rich and poor regions? since theory offers ambiguous answers to this fundamental question, empirical studies hold the key to unlock its gecrets. We believe that the late 19 th century offers one of the begt keys. There was economic convergence within the OECD club as a whole during this period, but the experience around the European periphery was hardly uniform. Some countries, like Ireland, converged on the economic leaders at about the expected rate; others, like the Scandinavians, converged at a ferocious rate; and still others, like the Iberians, failed to converge at all. Why did some nations around the periphery do so much better than others? What lessons for the present can we learn from this past?

Individual country experience reflects the combined influence of global forces, having a potential impact on everyone, and idiosyncratic forces, which are country-specific.

Education is a country-specific variable which has assumed great prominence in the historical debate on the European periphery and in the empirical growth literature. Robert Barro has argued that convergence is conditional on a satisfactory endowment of human capital; Lars Sandberg has argued that good education played an important role in Swedish catch-up; and Gabriel Tortella has argued that poor education helps explain Latin retardation. How important was schooling in explaining late 19th century catch-up and fall back around the periphery?

The global forces at work between 1870 and 1913 would now fall under the rubric of globalization: international labor, capital and commodity markets all became increasingly integrated. European labor migrated to the New World and from low-wage to high-wage European labor markets; Britain placed enormous amounts of capital overseas while France and Germany invested large amounts around the capital-scarce European periphery; transport costs plunged worldwide, subjecting Europe to an invasion of new world grain and heightened 
competition from each other. To what extent does participation in this growing international economy explain late 19th century scandinavian success? To what extent do Iberian efforts to insulate themselves from these forces explain their failure? And what about Ireland and Italy, lying in the middle of this range? How much of the catch-up and fall back performance around the periphery can be explained simply by the ability and willingness to emigrate?

\section{Globalization and Convergence: The Theoretical Debate}

Traditional trade theory is explicit about the link between economic integration and convergence. The argument is seen most clearly when applied to real wages. Consider the impact of commodity market integration. The Heckscher-Ohlin paradigm argues that countries export commodities which use intensively the factors with which they are well endowed while they import commodities which use intensively the factors with which they are poorly endowed. Let falling transport costs or trade liberalization tend to equalize prices of traded commodities. Countries will now export more of the goods which exploit their favorable factor endowment. The demand for the abundant and cheap factor booms while that for the scarce and expensive factor falls. Thus, commodity price convergence tends to produce factor price convergence. Real wages will rige in the labor-abundant periphery, while they will fall in the labor-scarce core.

of course, labor or capital mobility will also do the trick, as Robert Mundell (1957) recognized some time ago. Labor will flow from the periphery to the core in search of higher wages, raising peripheral wages and lowering core wages; capital will flow from the core to the periphery in search of higher returns, again lowering core wages and increasing peripheral wages. In the language of earlier debates on the same themes, these 'spread' effects will all serve to erode factor price differences between regions. As we shall see, however, some countries around the periphery exploited these Mundell effects well while others did so badly. Why? 
These standard trade-theoretic arguments all have implications for the convergence debate, a debate usually concerned with the convergence properties of aggregate indicators like GDP per worker. ${ }^{1}$ Let $Y$ be GDP, $P$ be the GDP implicit price deflator, $v_{\underline{i}}$ be the endowment of factor $i$ (where $v_{\underline{L}}=L$, the endowment of labor), and $w_{\underline{i}}$ be the price of factor $i$ (where $w_{\underline{L}}=w$, the wage). The factor income definition of GDP implies that

$$
Y / L=(W / P)\left\{1+\Sigma_{i \not L}\left(w_{i} v_{i}\right) /\left(w_{L} v_{L}\right)\right\}
$$

Thus convergence in GDP per worker is accounted for by three forces. First, there is the convergence in relative factor endowments per worker, $\left(v_{i} / v_{L}\right)$. This is the mechanism emphasized by solow, but open economy forces such as migration and international capital mobility will also help bring it about, perhaps much faster than in their absence. Second, there is the convergence in relative factor prices, $\left(w_{\underline{1}} / w_{\underline{L}}\right)$, which may again be a consequence of Solovian accumulation forces, but may also be due to open economy Heckscher-ohlin forces. Third, there is real wage convergence, which again may be due to either closed economy accumulation forces, or to open economy, factor and commodity market integration forces. Traditional trade theory thus predicts a strong link between economic integration and convergence, whether the latter be expressed in terms of factor prices or GDP aggregates.

In contrast, the "new" theory of economic geography is ambiguous on the question. Using a variety of models, Krugman and Venables $(1990,1995)$ explore the interactions between market size, economies of scale, and transport costa, and derive their now-famous U-shaped curves relating transport costs, on the one hand, to industry location and relative wages on the other. With economies of scale in manufacturing, there is an incentive for production to concentrate in one region. If manufacturing is labor-intensive, the low-wage periphery should exploit its comparative advantage and export

The following paragraph draws on O'Rourke, Taylor and Williamson 
manufactures. If trade barriers or transport costs are very high, shipping the good between markets will be expensive and production will take place in both the core and the periphery. However, if trade barriers or transport costs are at some intermediate level, it will be too expensive for the periphery to produce for consumption in the larger core market; but it will be cheap for the industrial core to produce for the small peripheral market. starting from very high trade barriers, liberalization first leads to falling production and wages in the periphery before leading to rising production and wages when trade barriers are very low. Market integration may involve an initial phase of divergence, followed by one of convergence: initially the core benefitg and the periphery 10ses, while eventually the periphery gains and the core loses. 2 The recent endogenous growth literature also has ambiguous implications for the globalization and convergence connection. several models have concluded that economic integration can produce divergence. A common feature of these models is that while poor countries may reap static benefits by moving to freer trade, these short run benefitg may be overwhelmed by long-run dynamic 1osses. ${ }^{3}$ others imply that trade liberalization can boost everyone's long run growth rate by, for example, speeding up international information flows and innovation. ${ }^{4}$ Grossman and Helpman (1991) conclude that both outcomes are possible $1^{5}$

Contrary to popular belief, recent theory has demonstrated that

2 As Barry (forthcoming) notes, this argument offers one way to interpret the evidence presented by Williamson (1964), who showed that in many countries long run regional inequality has increased before declining again.

3 stokey (1991) argues that the return to education, and hence investment in education, may fall in poor countries; Young (1991) argues that poor countries may specialize in commodities where learning by doing has been largely or completely exhausted.

4 Davis (1992) argues that trade boosts innovation by leading countries to specialize in production, allowing them to reap economies of scale in R\&D. See also Rivera-Batiz and Romer (1992).

5 On the one hand, poor countries will specialize in labor-intensive products, which may not amenable to much innovation; on the other hand, trade will reduce skilled wages in poor countries, making R\&D less expensive there. 
increasing returns and endogenous growth are not necessarily incompatible with trade leading to convergence. However, arguments can easily be erected supporting the view that trade leads to divergence. A key question remains: to what extent are the predictions of the (static) Heckscher-Ohlin trade model borne out by the evidence? Did commodity price convergence induce factor price convergence, as the theory suggests? If these stolper-samuelson effects are borne out by the evidence, it is more likely that the convergence conclusions of traditional neo-classical theory are valid.

In the end, these issues can only be resolved empirically. This paper contributes to the debate in a number of ways. Section 2 assesses the economic performance of the European periphery in the late 19th century, documenting where convergence and divergence took place. Section 3 provides a test of the Sandberg and Tortella hypothesis, estimating the impact of schooling on performance around the periphery. Sections 4 and 5 explore the role of emigration and international capital flowg in accounting for the variety around the European periphery, while section 6 looks at the role of declining transport costs and commercial policy. We offer a brief overall assessment and a research agenda in section 7 .

\section{DOCUNENTING PERFORMANCE AROUND THE PERIPHERY}

This section exploits four independent sources of evidence in an effort to gauge late $19 t h$ century performance around the periphery. The firgt contains purchasing-power-parlty adjusted real wages for the urban unskilled in sixteen countries (Williamson, 1995): four New World countries -Argentina, Australia, Canada, USA; five European industrial leaders forming the core -- Belgium, France, Germany, Great Britain and the Netherlands; and seven from the European periphery -- Denmark, Ireland, Italy, Norway, Portugal, spain and sweden. The second documents trends in the wage-rental ratio, the ratio of ungkilled urban wages to farm land values for ten of the Williamson sample (O'Rourke, Taylor and Williamson, 1993: excludes Belgium, 
Canada, Norway, the Netherlands, Italy and Portugal). The third contains some older constant price GNP per capita estimates which overlap with the Williamson European sample except for the exclusion of Ireland and Portugal (Bairoch, 1976a). Finally, the fourth contains modern GDP per worker-hour estimates which overlap with the Williamson sample except for Argentina and Ireland (Maddison 1994; Portugal, Spain and Italy repaired by Bardini, Carerras and Lains 1995: excludes Argentina and Ireland, but includes Austria, Finland and switzerland).

Apart from the fact that these data were constructed from different sources and by different scholars, they are unlikely to tell exactly the same convergence story. Per capita and per worker-hour convergence may differ according to trends in labor participation rates and length of the working day. If the forces of demographic transition are strongegt for the richer countries (higher fertility and lower lnfant mortality) -- causing population growth to exceed labor force growth, and if these forces are reinforced by a legiglated shortening in the length of the work week first in labor-scarce rich countries (who could best afford 1t), then it follows that per capita convergence will be fagter than per worker-hour convergence. If the forceg of international migration dominate instead, then the opposite would be true since migrants are mainly young adults. Second, GDP per worker-hour is, after all, nothing more than average labor productivity, and convergence of it and real wages may differ for various reasong. The real wage deflator may behave differently than the GDP deflator, an event which was especially true of the late 19th century when the price of foodstuffs fell sharply in the laborabundant old World, which imported these key wage goods, relative to the labor-scarce New World, which exported them. Thus, real wage convergence should have been more dramatic than GDP per-worker convergence on that score alone. This prediction is reinforced to the extent that the ratio of marginal labor productivity (i.e., the real wage) to average labor productivity (i.e., GDP per worker-hour) rose faster in land scarce, labor abundant poor countries than in land abundant, labor scarce rich countries. After all, farm land 
prices and rents collapsed in poor late 19th century Europe while they surged in the rich New World. It follows from this argument, third, that wage-rental ratio convergence should have been even more dramatic than real wage convergence because both wages and farm rents converged but in opposite directions, thus making wage-rental convergence faster than wages alone and certainly faster than some aggregate GDP measure which, among other things, aggregates up across rentg and wages. As we shall gee in a moment, the late 19 th century annual growth rates implied by all four indicators seem to accord well with these predictions, especially the prediction that factor prices should exhibit much more dramatic convergence than GDP aggregates.

Before we proceed with our narrative, let's first define the members of our European periphery sample. Table 1 reports 1870 real wages and GDP per head for fifteen European countries. The two development indices reveal similar rankings. Real wages in the periphery fell 20 percent below the European average, while GDP per head fell 22 percent below average. Similarly, the figures for the industrial core were 27 and 30 percent higher. Spanish real wages were (suspiciously) far higher than the periphery average, but GDP per head was lower. Apart from this ambiguous case, all nine members of the periphery were equal to or well below European averages. With the exception of German GDP per head, both indicators score well above average for the six members of the industrial core. These fifteen start as members of our European sample, and the members of the periphery are: Austria, Denmark, Finland, Ireland, Italy, Norway, Portugal, Spain and Sweden.

Let's start the narrative with the success up North, the spectacular Scandinavian catch up on the leaders. Consiatent with qualitative accounts, the evidence in Table 2 confirms that Sweden and Denmark tended to outperform Norway and Finland, but only Paul Bairoch's data (column 3) show a truly wide spread between the Nordic four. While Bairoch's GNP per capita figures show Sweden growing at twice the rate of Finland and almost twice the rate of Norway, Maddison's GDP per worker-hour figures (column 4) reveal only modest differences between them. The same is true of Williamson's real wage data 
(column 1), which show sweden growing only a little faster than the Scandinavian average ( 2.92 versus 2.60 percent per annum). In short, recent evidence suggests that rapid growth was common to all four Nordic countries. The scandinavian catch-up is certainly confirmed by the evidence in Table 2. Real wages grew at rates almost twice those prevailing in the European core; Swedish workers enjoyed real wage growth rates more than three times that of British workers; and Danish workers enjoyed real wage growth rates almost two and a half times that of German workers. In fact, there was no country elsewhere in our European sample that underwent real wage growth even close to that of Sweden, Denmark or Norway. What was true for real wages was also true for the wage-rental ratio. While the ratio of wage rates per worker to farm land values per acre fell everywhere in the New World, it rose everywhere in Europe (with the exception of Spain). These events reflect the invasion of graing from the New World (and Russia) which lowered farm rents and $l$ and values in Europe and raised them in the American Midwest, the Argentine pampas and elsewhere in New World granaries. While the Scandinavian wage-rental ratio seems to have tracked the British ratio very closely 12.65 versus 2.54 percent per annum growth), the ratio roge half again faster in Scandinavia than in the European core. Once again, factor prices converged more dramatically in scandinavia. Bairoch's per capita income figures document Scandinavian growth rates more than half again higher than those in the European core. Consistent with our predictions, Maddison's product per workerhour estimates document a less spectacular scandinavian catch-up, but even his data confirm a relatively impressive growth performance.

Scandinavia outperformed the rest of Europe (and probably the rest of the world) in the late 19 th century, of that there is no doubt. They were overachievers even by catching up standards. What about the rest of the periphery?

In contrast with Scandinavia, Ireland was no overachiever. While Ireland certainly catches up on the European industrial core, its catch up performance is about average. Real wages grew a little slower in Ireland than elsewhere 
around the periphery, but the wage-rental rose faster. Austria also seems to reveal about average catch up: GNP per capita and GDP per worker-hour grew almost exactly as fast there as in the rest of the periphery.

As a unit, the Mediterranean Basin, of course, did badly. Gabriel Tortella (1994a) has recently surveyed performance in the Basin, so we can be brief. The Iberian peninsula fell far behind the growth rateg recorded in the rest of the periphery. Real wages crawled upwards at 0.3 percent a year in Iberia, while they surged five times more quickly elsewhere around the periphery. While the wage-rental ratio rose at more than two percent a year around the periphery, it fell by one percent a year in Iberia. The same wide gap appears for Bairoch's GNP per capita data: growth of 0.2 percent per annum in Iberia and 1.2 percent per annum around the periphery. Maddison's real GDP per worker-hour data also confirm a poor Iberian performance, but the gap is nowhere near so great: 1.3 percent per annum in Iberia (slower than in the core, confirming Iberian "fall-back") and 1.6 percent per annum around the periphery. Italy does somewhat better, but even she -- except for real wages - falls below the average for the periphery.

Peripheral Performance in the Light of Convergence

Thus, we have three types of performers around the periphery: the overachieving catchers up (the Nordic four), the average catchers up (Austria and Ireland), and the underachieving fallers behind (the western Mediterranean Basin). This paper is motivated by this enormous variance, but note that on average there is evidence of convergence in Europe during the late 19th century. The periphery grew faster than the industrial core. Real wages grew almost twice as fast ( 1.65 versus 0.88 percent per annum). The wage-rental ratio grew significantly faster (2.16 versus 1.74 percent per annum). GNP per capita and GDP per worker-hour also grew faster, although the differences were far smaller than was true for factor prices (1.19 versus 1.11 and 1.60 versus 1.46 percent per annum). Thus, the periphery was catching up on the leaders in 
Europe. Furthermore, factor prices in the labor abundant periphery were also converging on the labor scarce New World: real wages grew almost twice as fast; and while the wage-rental ratio around the old World periphery boomed at more than 2 percent per annum, it fell in the New World at 3 percent per annum.

Economists have come to expect this kind of performance: as long as they are members of the "club", poor countries tend to grow faster than rich countries, factor prices converge, and living standard gaps between them tend to erode with time. This convergence can be due to solovian forces of accumulation and capital deepening; or to the forces of technology diffusion identified by Alexander Gerschenkron (1962), with convergence being assured if "social capability" conditions are satisfied (Abramovitz, 1986); or to the globalization effects stressed in this paper, associated with international trade and factor flows. What determines memberahip in the convergence club is, of courge, another matter entirely. 6

Although economic historians had been talking about it for years, convergence in the OECD club was documented with hard evidence only fairly recently (Abramovitz 1986; Baumol 1986; Baumol et al., 1989, Chp. 5; Prados, Sanchez and Oliva, 1993; O'Rourke and Williamson 1996; Williamson 1996). Typically, these studies rely solely on Maddison's aggregate labor productivity estimates, but they have been confirmed recently by real wage experience (Williamson, 1995; 1996). Indeed, Williamson's real wage information has added a number of new facts to the debate. First, real wages converged at more rapid rates than did average labor productivity. Second,

6 To repeat, this paper will focus on the sources of catch up around the European periphery in the late 19th century, hoping to get further insight into the forces driving convergence within the OECD club. We have nothing to say about what determines membership in the club. However, we are well aware that European convergence may have been limited to the club. Indeed, while Table 2 offers some weak evidence of GNP per capita convergence using Bairoch's data on the OECD club, there is no evidence of convergence when the Bairoch's full sample is used (that is, when such central, south and east European countries like Austria-Hungary, Bulgaria, Greece and Russia are added). The point was made with clarity by $J$. Bradford Delong (1988) in his debate with William Baumol (1986). The same is true of GDP per worker-hour in the conditional equations reported in Table 5. When Austria, Finland and Switzerland are added, the results are far weaker. 
although real wage convergence during the late 19th century was pronounced, it was less dramatic than it was during the more familiar post World War II decades. Third, secular convergence ceased between 1914 and 1950 . This, of course, was also a period of quotas on New World immigration, a collapse in world capital markets, and a surge in commodity protection. Global openness and convergence seem to be positively correlated; global autarky and convergence seem to be negatively correlated. Fourth, much of the late 19th century convergence documented for the OECD club was explained by the erosion in the gap between the labor-gcarce, land-abundant New World and the laborabundant, land-scarce old World. To restrict the analysis of late 19th century convergence to Europe is to miss the most important catching up event of the period, namely, the old World -- including much of the periphery -- catching up on the New.

Scandinavia was central to OECD convergence in the late 19th century, but did it grow as fast as convergence models predict? or did it grow faster? Was Ireland really "average"? And how far below the prediction of a convergence model was the Mediterranean Basin? Figure 1 supplies an answer using real wages, 7 and Table 3 reports the underlying unconditional convergence regressions for real wages as well as for GDP per worker-hour and GNP per capita. ${ }^{8}$ The equation estimated is widely used in the convergence

7 The $\beta$ underlying Figure 1 is -0.390 (Table 3, row 1, entry 1). The rate of convergence is

$$
\lambda=(1 / t) \ln (\beta+1)
$$

where $t$ is the time span ( 43 years) and $\beta$ is the coefficient for the log of initial real wages, income per capita or labor productivity. Actually, we use the term "speed of convergence" too loosely in this context. Speed of convergence technically is $\lambda$ times the initial gap. If $\lambda=0.01$, then it would take 70 years to cut the gaps in half. Thus, had the late $19 t h$ century rate of convergence persisted, by 1940 gaps would have been half that of 1870 . Eliminating big initial gaps takes a long time, even when there is fast convergence at work.

8 The words "conditional" and "unconditional" come from the empirical work of the new growth empiriciets like Robert Barro and Xavier Sala-i-Martin (1992), and Gregory Mankiw, David Romer and David Weil (1992). They refer to convergence conditional on, or after controlling for, schooling and other forces excluded from the standard solow model.

The Maddison sample for the regressions in both Tables 3 and 4 exclude 
Iiterature (Barro 1991; Barro and Sala-i-Martin 1991; Mankiw et al. 1992;

Barro and Sala-i-Martin 1992; Prados, Sanchez and oliva 1993). Thus, in the

first row of Table 3 a measure of late 19th century real wage growth (the

difference in the logarithms of real wages, 1913 versus 1870) is simply

regressed on the logarithm of the real wage in 1870. Each row confirms

"unconditional" convergence -- i.e., the coefficient is negative, although the

real wages underlying row 1 not only converged much faster than GDP per worker

and GNP per capita, but the t-statistic on the latter two are very low.

Indeed, with each revision of Angus Maddison's GDP per worker-hour data, the

evidence of convergence seems to slip further away. Maddison's 1982 data

showed strong convergence (Williamson 1995), but it did not include Latin

American, Iberia or Ireland. The rate of convergence $(\lambda)$ underlying Maddison's

1982 and 1994 GDP per worker-hour data is very close to that estimated

recently by Leandro Prados and his collaborators (1993: Table 4); they report

$\lambda$ ranging between .009 and 0.010 for a pre-World War I European sample

including Belgium, Denmark, France, Germany, the Netherlands, Sweden,

Switzerland, and the United Kingdom. When Maddison's revised 1994 sample uses

more recent estimates for Italy, spain and Portugal (Bardini, Carerras and

Lains 1995), unconditional convergence pretty much disappears (row 2, Table

3). Theory predictg factor price convergence, but it is less certain about GDP

per worker hour convergence. History seems to be consistent with theory.

Even if one is skeptical about the evidence supporting convergence in

the late 19th century Atlantic economy, an important question still remains:

What accounts for the enormous variety in performance around the European

periphery in the late 19 th century? Was it schooling that mattered? Different

rates of emigration and capital inflows from abroad? The choice between free

Austria, Finland and Switzerland so as to make it as comparable with the real wage sample as possible. However, when these three countries are thrown back in to the sample, the unconditional and conditional convergence results are much poorer. To repeat: the real wage sample includes Argentina, Australia, Belgium, Canada, Denmark, France, Germany, Great Britain, Ireland, Italy, the Netherlands, Norway, Portugal, Spain, Sweden and the United States; the

"overlapping" GDP per worker sample includes all of these except Argentina and Ireland. 
trade and protection? Cultural-based mysteries?

\title{
3. SChOOLING, CATCH-UP AND FAIL-BACK
}

\begin{abstract}
Given the simplicity of the "unconditional" convergence equations egtimated in the previous section, it is a wonder that any of them are statigtically gignificant. Certainly the new growth theorists have been motivated by that fact when deriving "conditional" convergence equations. Thus, the standard conditional convergence equation (e.g., Mankiw et al.,
\end{abstract} 1992, p. 426) includes labor force growth, investment shares in output and schooling. As far as we are aware, only Leandro Prados and his collaborators (Prados, Sanchez and Oliva 1993) have attempted to estimate convergence equations over two centuries conditional on schooling. However, they do not report results for the late 19 th century separately, nor do they tell us how much of catch-up and fall-back might be assigned to education. It is essential to fill in those blanks gince so many historians have asserted that favorable Scandinavian education was absolutely fundamental to its ability to catch-up on the leaderg prior to World war $I$, or that unfavorable Iberian education was crucial in holding growth back. However, while the thesis is useful for explaining catch up in the late 20th century, it is not obvious why it must also apply to the late 19th century. After all, technologies were much legs schooling-intensive then. Nonetheless, the proposition needs a serious test given the contrary views of most economic historians.

In 1979, Lars Sandberg published a wonderfully ouggestive paper entitled "The Case of the Impoverished sophisticate" which explored the relationship between schooling and swedish economic growth before World War I. Sandberg did not offer an explicit test of his schooling hypothesis at that time, but no one, including the new growth theorists or Richard Easterlin in his 1981 presidential address to the American Economic History Association, has stated the proposition with greater clarity. While "catching up" was not quite part of the economist's language in 1979, Sandberg was motivated by the 
speed of Swedish late 19th century growth:

"It is ... my contention that the speed of Sweden's pre-World War I economic growth and industrialization was to a significant degree a result of the country's disproportionately large initial stock of [human capital] (1979: 228)."

The human capital that sandberg thought mattered most was schooling and literacy. Lennart Jörberg (1969: 275; 1970: 386 and 396) and K.-G. Hildebrand (1978: 603) said as much in earlier surveys, but they did not develop the argument with the care that Sandberg did. Carlo Cipolla (1969) certainly offered plenty of evidence supporting the impoverished sophisticate view. Cipolla documented (1969: Table 6) high literacy levels in scandinavia compared with the rest of Europe and, based on such evidence, argued that the "more literate countries were the first to import the Industrial Revolution (p. 87)." By 1850, Sweden was the most literate country in Europe and was the only European country that could measure up to the United states in that dimension (Sandberg 1979: 230).9 Indeed, in a later paper sandberg used Cipolla's 1850 qualitative data on literacy to show that the 1850 educational ranking was highly correlated with the 1970 per capita income ranking, and that up to 1913

"the poor, high literacy countries... grew the fastest ... As for the low literacy countries, this group's growth rate was clearly slower than that of the others (Sandberg 1982: 689)."

Gabriel Tortella (1994a) has recently elaborated on this latter observation to find explanations for economic retardation in the Mediterranean Basin, and Clara-Eugenia Nuñez (1990) has done the same for regions within spain. These important studies fall short of our goal. They look for correlations in the data, rather than assess the contribution of schooling to catching up (or falling behind). They do not aupply an answer to the question:

\footnotetext{
9Others have pursued this connection between education and economic performance in sweden since Sandberg's paper appeared, and some are critical of the impoverished sophisticate hypothesis (e.g., Nilsson and Pettersson 1990, 1992; Markussen, 1990).
} 
How much of catch-up and fall-back around the late 19th century European periphery can be explained by schooling endowments? Only one, in fact, attempts to estimate convergence equations conditional on schooling. As we pointed out above, Leandro Prados and his collaborators (Prados, Sanchez and Oliva 1993) have recently done so, but there is reason to do more since they: only perform the tests on the rate of growth of GDP per capita; only include a limited number of OECD club members in their "core" convergence club (excluding all of the New World, for example); do not report results separately for the late 19th century, but rather only for the complete modern era 1820-1990, when there is reason to expect very different convergence dynamics within shorter epochs (Williamson 1995; 1996); and (last but surely not least) consistently report poor results on the schooling variable (Prados, Sanchez and Oliva 1993: Tables 14-16, "escolar").

The new growth empiricists use school enrollment rates as a proxy for average educational achievement in analyzing conditional convergence in the post World War II period. Table 4 offers late 19th century enrollment rates in column (1), typically taken as mid-point averages for the four decades as a whole. If we exclude Finland from the scandinavian average, then the impoverished Scandinavian three measure up very well with the rest of Europe $(0.66 / 0.56$ or 188 above the European average). So too does Austria. Ireland does less well, falling a good bit below the rest of Europe $10.45 / 0.56$ or 208 below). Italy does even worse, 348 below the European average, while the Iberian two bring up the rear at 388 below average. Column (2) offers some literacy rate estimates: the European figures are those reported for (mainly young adult) immigrants by United States authorities in the 1890s (with the exception of Spain), while the New World estimates are for adult residents. According to this measure, all four of the Nordic countries are now well above the European average, 238 higher. Once again, Italy is below average, this time 40 lower. The Iberian two bring up rear again, 498 below average. So far, the two measures of schooling are surprisingly consistent. Ireland is the 
deviant. ${ }^{10}$ Irish 1iteracy is far better than her enrollment rates; indeed, the former is 178 higher than the European average, while the latter is 208 lower. Column (3) offers yet another enrollment rate estimate, this one from Leandro Prados and his collaborators. While each of these three measures of schooling is imperfect, they appear to tell roughly the same story, except, perhaps, for Ireland.

There was certainly variety in school enrollment and literacy rates around the European periphery. The Scandinavian countries had a bigger education endowment than they could, in some sense, afford." The Iberian countries had a smaller education endowment than they could, in some sense, afford. Ireland and Italy (plus Austria) were somewhere in between. This schooling endowment variety around the impoverished European periphery must have been driven by non-economic forces, embedded in a path-dependent history prior to the late 19th century. The interesting questions, however, are these three: Does schooling explain much of late 19th century convergence in the OECD club? Does schooling explain much of the growth performance around the European periphery? Does schooling explain much of Scandinavian, Italian and Irish catch-up on the leaders, or of Iberian fall-back?

Some answers to the first question -- does schooling account for much of the catch-up in the OECD club? -- appear in in Panel $A$ of Table 5 where convergence equations are conditioned by schooling, the latter proxied first by enroliment rates (the standard proxy) and second by literacy rates. The conditional convergence equations were estimated on both real wage and GDP per worker data. The contribution of schooling to GDP per worker growth and real wage growth is statistically significant in every case, supporting the view

10 The same is true of Great Britain, which sugge日ts it may have something to do with how students were counted or literacy was assessed in the United Kingdom compared with the Continent.

11Markussen (1990: 37) has stressed that the Nordic countries were unique in that there was a long lag, perhaps 100-150 years, between development of reading and writing skills. Indeed, while their reading skills and enrollment rates are well above what one would expect for poor countries (Table 4), Markussen (1990: Table 1) shows that they were well below in writing skills at least based on per capita letters and postcards sent. 
that schooling was important to late 19 th century growth. 12 As predicted by Abramovitz, Easterlin, Sandberg, Tortella and the new growth theorists, schooling levels "conditioned" real wage convergence in the late 19th century. Poor countries well endowed with schooling caught up faster than those poorly endowed, presumably because their "gocial capabilities" were better established. That is, they were better able to exploit open economy and globalization effects or were better able to absorb new technologies transfered from the leaders. Furthermore, when conditioned by schooling, the rate of real wage convergence $(\lambda)$ rises from 1.1 to 1.7 or 1.8 percent per annum, and the rate of GDP per worker convergence rises from 0.1 percent per annum (and statistically insignificant) to 0.4 or 0.8 percent per annum (and statistically significant). Note, however, that the rate of real wage convergence in Panel $A$ is still at least twice as fast as that for GDP per worker, again consistent with theory that suggest faster factor price convergence than GDP per worker-hour convergence.

What we really want to know, however, is whether schooling played a central role in accounting for Scandinavian, Italian and Irish convergence, and for Iberian divergence. We can find out by asking a second question: How much of each country's "deviant" growth performance between 1870 and 1913 was due to each country's "deviant" schooling performance? As the notes to Panel B in Table 5 indicate, "deviant" growth is defined as the residual left over after controlling for initial real wage levels, while "deviant" schooling is simply how much it exceeded the average. Panel $B$ answers the question. In twelve of thirty-two cases schooling didn't matter at all. These were almost always European industrial leaders who, presumably, had already fulfilled some minimum schooling pre-condition. But schooling did matter for

12 This result is surprising. After all, the real wage growth is for "raw" unskilled labor and only measures changing labor scarcity and labor productivity within one (un)skilled category. GDP per worker-hour growth aggregates the impact of changing labor productivity within skill categories and changing labor productivity due to country-wide shifts up the skili ladder. We have also experimented with the addition of changes in schooling, but the results were poor. Table 5 and the text sticks, therefore, with levels of schooling on the right hand side, as does most of the empirical new growth literature. 
about a third of "deviant" good growth among the Scandinavian three: good schooling accounted for 15-31 percent of "deviant" good growth in Sweden; for 27-40 percent in Denmark; and for 26-57 percent in Norway. Schooling did not account for a third of late 19th century scandinavian growth. It did not account for a third of growth above average. It did not account for a third of catch up. It did account for a third of the residual growth after controlling for initial 1870 conditions. We will argue below that those initial conditions were associated with open economy and globalization forces: poor scandinavian countries sending out emigrants; rich New World and rich old World countries absorbing immigrants; and trade between the rich leaders and the poor Scandinavian followers inducing factor price convergence.

The figures are even bigger for the Mediterranean Basin. Bad schooling accounted for almost all of the "deviant" bad growth in Italy. That ig, Italy did catch up on the leaders, but she caught up at a slower rate than she should have given initial development levels in 1870, and a bad schooling endowment helps account for that fact. And bad schooling accounted for a large share of "deviant" bad growth in Iberia (from 11 to 75\%). For Ireland, it depends on which schooling variable one favors: bad enrollment rates accounted for none of Irish "deviant" good growth, while good literacy rates accounted for all of it.

What about the third question? That is, how much of the gap in real wage growth between each of these seven countries around the European periphery and Britain was due to schooling? The answers are offered in Panel B.2 of Table 5. start with the Scandinavian three, where the schooling thesis has had the strongest following, and let us focus on enrollment rates where the econometric results are strongest. Here the figures are: 15 percent for Denmark, 10 percent for Norway and 8 percent for Sweden or an overall Scandinavian average of 11 percent. It looks like Sandberg is right, although 
these must be viewed as upper bounds. ${ }^{13}$ In any case, we should stress that schooling explains none of the Scandinavian convergence on the United States since the latter had higher literacy and enrollment rates. Now consider the Iberian Peninsula where the figures are 12 percent for spain and all for Portugal; these imply an overall average of 56 percent for the Iberians; that is, more than half of the Iberian "fall back" was due to very poor schooling. ${ }^{14}$ In contrast, schooling explains none of the Italian real wage catch-up on Britain. It looks like Tortella is only partly right: schooling mattered in only one part of the Mediteranean Basin. Moreover, schooling explains none of the Irish catch-up on Britain.

Schooling mattered to catch up and fall-back around the European periphery, but itg impact was limited to Scandinavia and Iberia, and, as we shall see, in only one case, Iberia, does it look like schooling might have mattered as much as globalization forces.

\section{THE IMPACT OF EMIORATION}

Did emigration from Scandinavia help create labor scarcity and thus catch up? scandinavian emigration rates reached their peak in the 1880s, and at that time they were among the highest in Europe, exceeded only by Ireland and the rest of the United Kingdom. The rate for the decade was 95.2 per thousand of the population in Norway, 70.1 per thousand in Sweden and 39.4 per thousand in Denmark (Hatton and Williamson, 1994a: Table 1.1): Sweden lay in the middle of the Scandinavian range. Emigration went through booms and busts, but by 1910 the Danish population was 11 percent below what it would have been

\footnotetext{
${ }^{13}$ These schooling calculations are based on country enrollment rate differentials and the 0.349 estimated coefficient reported in Table 5 . They are much smaller if the literacy differentials and the 0.531 estimated coefficient are used, ranging from 1 to 2 percent. Thus, the text overstates the contribution of schooling to late 19th century Scandinavian convergence.

14 And if literacy rather than enrollment rates are used, poor schooling explaing all the Iberian fallback.
} 
in the absence of emigration over the four decades following 1870, the Swedish population was 15 percent lower and Norwegian population 19 percent lower (Taylor and Williamson 1994: Table 1). Since emigration favored young adults with high labor participation rates, the impact on the home labor force was even bigger than on the home population: the Swedish labor force was perhaps 18.1 percent smaller in 1910 than it would have been in the absence of emigration (O'Rourke and Williamson 1995: Appendix Table 2.1).

With the estimated labor force impact in hand, a recent paper of ours posed the following question ( $O^{\prime}$ Rourke and Williamson 1995): How much of Swedish catch-up could be assigned to mass migration, the latter including both the emigrations from Sweden and the migrations experienced by the leaders, Britain and the United States? Using CGE models, we estimated that mass migration accounted for more than 10 percent of the rapidly contracting wage gap between Britain and Sweden (0'Rourke and Williamson 1995: Table 1). This estimate is revised a bit downwards in Table 6 (col. 4b) to 8.4 percent. ${ }^{15}$ That is, the Anglo-Swedish wage gap fell by 144.3 percentage points between $1870(139.38)$ and $1910(-58)$, and migration accounted for 12.1 percentage points of it. The reason why the figure isn't a lot bigger is that Britain recorded an impressive emigration rate too. But what about Swedish catch-up with the United States, the country which absorbed most of the Swedish emigrants? The immigration rate in late 19th century United States (of Swedes and non-Swedes combined) served to make the 1910 labor force there 21 percent higher (Table 6, col. 2b) than it would have been in its absence, making urban wages 15.1 percent lower (Table 6, col. 3b) than they would have been without the immigration. The American-Swedish wage gap fell by 240.7 percentage points between 1870 (310.78) and 1910 (70.08), and mass migration accounted for 41.6 percent of it (100.2 percentage points).

So much for Sweden. What about the rest of Scandinavia? While Swedish

15 The difference is due to the fact that Table 6 uses annual real wage data for 1870 and 1910, while our earlier estimate used three year averages centered on those years. While we prefer the three-year averages, we cannot get them for all the countries around the periphery. 
emigration after 1870 served to diminigh the Swedish labor force in 1910 by a little more than 18 percent, it served to diminish the Danish labor force by 12 percent and the Norwegian labor force by 22 percent (Taylor and Williamson 1994, Table 1). Given these migration-induced labor force effects, and assuming that the wage-elasticities implied by the swedish CGE apply to the rest of Scandinavia as well (-.6796), then we can estimate the impact of mass migration on Danish and Norwegian convergence too -- the rest of scandinavia "viewed in the Swedish mirror" if you will (0'Rourke and Williamson 1996). Columns (4b) and (5b) in Table 6 suggest that mass migration must have contributed less to Danish convergence on Britain ( 3.1 percent) and America (46.6 percent), but more to Norwegian convergence on Britain (16.9 percent) and America (64 percent).

What about elsewhere around the European periphery? since it seems inappropriate to view the rest of the periphery in the swedish mirror, and since there are no CGE models yet available for the Mediterranean Basin, we elect instead to use the work provided by Alan Taylor and Jeffrey Williamson (1995) who offered independent estimates of the impact of the mass migrations 1870-1910 on the labor force in all nine countries listed in the first panel of Table 6 (col. 2a) and assessed its impact econometrically on 1910 real wages (col. 3a). As the reader can verify, the two estimates are reasonably close for the five overlapping countries $1001.2 a$ versus $2 b$, and col. $3 a$ versus $3 \mathrm{~b}$ ). We shall use the estimates labeled "a" in everything that follows. Note first that emigration rates from the poor periphery ranged enormously: they were huge for Ireland and Italy; they were large for Scandinavia; and they were tiny for Iberia, even smaller than Britain. The cumulative impact on the labor force at home also varied enormously: it served to lower the Irish 1910 labor force by almost a half (45 percent) and the Italian 1910 labor force by more than a third (39 percent); it served to lower the Scandinavian labor force by from 14 to 24 percent; but it Berved to lower the Iberian labor force by only 5 to 6 percent. Note further that rich Britain also emigrated, so that her labor force was diminished by 11 percent, a much 
blgger impact than was true of Iberia. Finally, immigration appears to have augmented the United States labor force by 24 percent.

Col. (3a) records the impact of these mass-migration-induced labor force changes on real wages, and the second panel of Table 6 reports the bottom line: namely, the share of the observed real wage convergence of the European periphery on Britain and America accounted for by mass migration.

The figures for Ireland and Italy are huge: mass migration accounted for all of the convergence for those two countries. The amazing characteristic of these two countries is that they seem to have relied exclusively on emigration to achieve some convergence on the leaders. ${ }^{16}$ We should be sensitive to the possibility that it was unimpressive industrialization at home which helps account for those high Irish and Italian emigration rates, but recall that Table 5 (Panel B.2) suggested that schooling could not account for any of the convergence of these two countries on the leaders.

Portugal and spain, on the other hand, were unable to exploit emigration possibilities. A significant share of their divergence from Britain is explained by "under-emigration" (about 3-11 percent for spain and about 15-54 percent for Portugal). This is not to say that more fundamental problems underlay Iberian performance. Even if the Spanish and Portuguese emigration rates had induced the same labor force impact as in Norway, these two countries still would have undergone retardation relative to Britain. The "n.a." (not applicable) under cols. (5a) and (5b) simply means that while mass migration should have helped produce Iberian convergence on the United Stateg, divergence factors overwhelmed these forces.

Scandinavia lies in between these extremes: on average, a little less than a tenth of the Scandinavian convergence on Britain was due to mass migration, while the figure is more than half for the convergence on the United States.

The mass migrations explain a very large share of the convergence and (1995).

16 For more on the Irish experience, see Williamson (1994) and O'Rourke 
its absence around the European periphery. Why did emigration rates vary so much? Why did Iberia fail to exploit this powerful source of catch-up? Timothy Hatton and Jeffrey Williamson (1994c) have shown that a culture-specific "Latin" explanation is not needed to account for those low rates in Iberia, but rather that a common model of European emigration can do the job quite nicely. The model is complex, but the key insight that applies here is the following: Since long distance moves are expensive, desperate poverty delays (free) emigration. Labor in the poorest parts of the periphery couldn't finance the move (i.e., the Portuguese), while labor in the less poor parts of the periphery could (i.e., the Irish). Furthermore, those who sent out emigrants first in the $1840 \mathrm{~s}$ and $1850 \mathrm{~s}$ could use the remittances from those pioneers to finance the moves of others following later. Thus, by the $1880 \mathrm{~s}$ it was the Irish and the Scandinavians who were best able to exploit emigration as a convergence force, not the Iberians who had the most to gain from mass migration.

Mass migration is one aspect of late 19th century globalization that mattered a great deal. The problem, of course, is that the mass migrations must have been intimately related to international capital flows, trade and industrialization.

\section{THE IMPACT OF INYGRATIONAL CAPITAL FLOWS}

From a global perspective, international capital flowg were a force for divergence in the late 19th century. After all, low wage Europe was a net capital exporter, while the high wage New World was a net capital importer. To explain this apparent paradox, we need not appeal to Lucas-like externalities (Lucas 1990), or to other new growth theory exotica; rather, we need only appeal to the existence of a third factor, land, and the role of the overseas frontier, pulling both labor and capital from poor to rich countries, as historians have long recognized.

Nevertheless, there were also substantial capital flows within Europe 
during the late 19th century, with France and Germany taking the lead in lending to the European periphery. Less than 6 percent of British investments were in Europe at the end of 1913 (Feis 1930: 23); but the figure for France was 61 percent (p. 51), and the figure for Germany was 53 percent (p. 74). To what extent did these capital flows account for the Scandinavian catch-up?

We know that Sweden absorbed exceptionally heavy doses of foreign capital. It was directed into Swedish cities and the railroads, and it was in response to government demand. Most of these capital inflows were used to finance social overhead construction and France was the main market for the Swedish bond issues. A previous paper (O'Rourke and Williamson 1995) showed how important British capital exports, and US and Swedish capital imports, were for their respective capital stocks. As Table 7 indicates, capital imports over the four decades following 1870 served to make the 1910 Swedish capital stock 50.1 percent bigger than it would have been in its absence. Capital exports served to make the 1910 British capital stock 20.4 percent smaller than it would have been in its absence. The United States was a much more modest capital importer than was Sweden (capital inflows only augmented its 1910 capital stock by 0.3 percent), so global capital markets should have contributed to Swedish catch-up on America, although much less than in the Anglo-Swedish case.

Once again using CGE models, we estimated that international capital flows accounted for more than a half of the decline in the Anglo-swedish wage gap, and more than four-tenths of the decline in the US-Swedish wage gap (0'Rourke and Williamson 1995: Table 1). The figures reported in Table 7 are a bit smaller, 43 percent and 34 percent respectively. ${ }^{17}$ The results thus appear to support Heckscher's contention that the capital import between 1860 and 1910 "was a vital prerequisite for the country's rapid economic upswing" (Heckscher 1954: 210). What about the rest of scandinavia? The contribution of foreign capital imports to Danish convergence was likely to have been

17 To repeat, the revision is due to the fact that we are not using three-year averages for 1870 and 1910 , as we did in the earlier paper. 
considerably smaller since they financed a smaller share of domestic accumulation there (Johansen 1985: 230-2; Hansen 1970: 59-64; Jörberg 1970: 478-9). We have estimated that foreign capital imports served to make the 1910 Danish capital stock 16.3 percent bigger than it would have been in its absence (O'Rourke and Williamson 1996). Norwegian capital imports were also gmaller than for Sweden (Riis and Thonstad 1989). Although Norwegian capital imports were even larger than for Sweden after 1890, Norway was actually a net capital exporter 1870-1890, so the net impact of foreign capital on the 1910 Norwegian capital stock was to raise it by "only" 17.4 percent. Thus, the contribution of capital imports to Norwegian wage convergence on Britain or America, while still big, was smaller (about 34 and 20 percent) than to Swedish wage convergence (about 43 and 34 percent). The figures for Danish convergence are similar to those for Norway (about 30 and 16 percent).

Capital flows thus made a substantial contribution to scandinavian convergence on the core during the late 19th centuries. What about the celtic and Mediterranean peripheries? Did international capital flows make a powerful contribution to living standard improvement in these countries too? It is difficult to know, for the simple reason that good balance of payments data are only rarely available for this part of Europe. However, such data as we have tell a surprising story.

We do not know whether Ireland exported or imported capital during the late 19th century since trade statistica were not collected after the customs union with Britain in the mid-1820s. The indications, however, are that postFamine Ireland ran trade surpluses. Indeed, in his evidence to a 1895 Royal Commigsion, Robert Giffen estimated that Ireland ran a trade surplus of $\mathrm{f5.5}$ $m$. in $1893 .^{18}$ It seems likely that for most of the 19 th century Ireland was

18 Royal Commigsion on the "Financial Relation Between Great Britain and Ireland," Second Volume of Minutes of Evidence, London (HMSO), 1895 [C. 8008], p. 174 (Supplement to Table III).

When official Irigh trade statistics began to be compiled in 1904, they showed a mixed pattern but with deficits more common up to 1913 . Report on the Trade in Imports and Exports at Irish Ports During the Year Ended 318t December, 1914, Department of Agriculture and Technical Instruction for Ireland, Dublin (1916) [Cd. 8208], p. vi. 
running trade surpluses. One cannot conclude from this fact alone that Ireland was running current account surpluges, since there was also an 'economic drain consisting of rents remitted to absentee landlords and excess taxation paid to the British Exchequer. ${ }^{19}$ However, Giffen concluded that Ireland was probably a net capital exporter, and modern Irish historians have speculated that after 1860 "Ireland's position on capital account ... moved from net debtor to net creditor status" (Kennedy 1995: 108).

Thus, Ireland probably experienced net capital outflows during the late 19th century. Since the US was a net capital importer, capital flows were clearly a force for Irish-American divergence, rather than convergence; since one can only assume that Britain exported even more capital than Ireland, capital flows must have been a (small) force for Anglo-Irish convergence. Capital flows may have implied both Irish catch-up and fall-back, depending on which leader is being considered.

A similar picture emerges from official Italian statistics. True, the merchandise trade account was substantially negative throughout the period, but invisible earnings (tourism and shipping) helped offset this to a considerable extent, and in some years were enough to lead to a trade balance surplus. Net factor income from abroad was negative in the 19 th century, but positive after 1900, as emigrants' remittances more than offset income earned by foreign capital in Italy (Zamagni 1993: 126-7). Official balance of payments statistics reveal substantial capital imports in the 1860 s and late 18808, and substantial capital exports from 1894 to 1907.20 Over the entire period between 1870 and 1913, the official statiatics suggest that there were net capital exports from Italy, a force for divergence rather than convergence.

However, the Italian official statistics have been questioned by

19 See for example the discussion in the 1895 Royal Commission's minutes of evidence (op. cit.: 3-4) or Solar (1979: 24).

20 The Italian capital imports figures are given in Fenoaltea (1988: Table 4, 620-21). 
Giovanni Federico, among others. Certainly the qualitative literature emphasizes capital imports, especially in the 1880 s (when state bonds were sold) and the turn of the century (when direct investments became more important). These uncertainties are reflected in Table 7 .

The conventional wisdom for spain has been that the country ran large deficits on current account; and Broder's (1976) estimates indicate capital inflows throughout the period. However, Leandro Prados (1988: 188-97) has challenged this view. His estimates suggegt continuous merchandise trade surpluses from 1875 to 1912 (barring 1876 and 1883).21 Prados surmizes that the current account balance was in deficit between 1850 and 1890 , as remittances and the merchandise trade surplus were smaller than they were after 1900, and payments to foreign capital were larger. A plausible picture is one of deficits between 1870 and 1890, surpluses after the depreciation and tariffs of 1891, deficits around the turn of the century, and surpluses in the decade before World War I. Net capital inflows must have been small; even Broder's figures suggest that they accounted only for around 7 percent of gross domestic fixed capital formation between 1890 and 1913.22

Current account data are also lacking for Portugal. Pedro Lains (1992) has revised the official trade statistics, making the balance of trade deficits much smaller than official estimates had indicated. Moreover, emigrant remittances were also an important component of the Portuguese balance of payments. Reis' (1991) figures suggest capital inflows between 1865 and 1890. On the other hand, Salazar (1916) claimed that capital fled Portugal after the 1891 financial crisis, that it returned after the 1902 agreement with foreign creditors; and that it fled again in 1907, in response to the

21 Prados (1988: 252-4).

22 Based on unpublished estimates by Prados. The discrepancy between Prados' guesstimates of the current account, based on his trade estimates, and Broder's capital inflow figures, is very puzzling. Either Broder's estimates (admittedly sparsely documented) are wrong; or Prados' trade figures are wrong (a possibility favored by Tortella, 1994b); or spain was running exceptionally large deficits on the invisibles account. 
dictatorial government of Joāo Franco. ${ }^{23}$ The safest assessment would seem to be that capital imports can only have made a relatively small contribution to the Portuguese capital stock in the late 19 th century. 24

There are three main conclusions to be drawn from this brief tour around the European periphery. First, we urgently need balance of payments data for the Celtic and Mediterranean fringe. Second (and more tentatively), capital flows probably did not greatly reduce wage gaps between the us and the European periphery, except in the case of Scandinavia; but large British capital outflows meant that international capital markets were reducing wage gaps between Britain and the entire periphery. Third, the development of global capital markets is not by itself enough to guarantee that capital will chase cheap labor. Capital inflows may have made an important contribution to Scandinavian development, but they made no contribution at all to Irigh (and possibly Italian) catch-up, and only a tiny contribution to that of Iberia. Precisely why capital did not flow to some poor countries remains an enduring puzzle: possible explanations include insecurity of Irish property; the Iberian abandonment of the Gold standard; and cultural mysteries.

\section{TRADE, TARIFF, AND ECONOMIC CONYERGENCE}

What was the impact of trade on the European periphery? The late 19th century was a period of dramatic commodity market integration: railways and steamships lowered transport costs, and Europe moved towards free trade in the wake of the 1860 Cobden-Chevalier treaty. These developments implied large trade-creating price shocks which affected every European participant, the cannonical case being the drop in European grain prices. Eli Heckscher and

23 Cited in Lains (1992: 215-6).

24 Mata (1995) suggests that capital inflows can only have had a small aggregate impact on the Portugese economy, but that they were important in particular eectors. His numbers suggest that foreign capital accounted for 128 of net investment between 1851 and 1890 , and 428 of net investment between 1891 and 1913. However, he uses official trade statistics; using Lains' revisions would imply much smaller numbers. 
Bertil ohlin argued that such commodity market integration should have led to international factor price convergence, as countries everywhere expanded the production and export of commodities which used their abundant (and cheap) factors relatively intensively. For poor labor-abundant and land scarce countries, this meant rising wages and falling rents. In an earlier paper (O'Rourke and Williamson 1994), we showed that the reduction in trans-Atlantic transport costs had a profound impact on British factor prices, and explained a large fraction of that country's real wage convergence on the US. Can this finding be generalized? Did peripheral countries who actively participated in the development of a global economy undergo more dramatic real wage and labor productivity growth than those who tried to insulate themselves from international market forces?

There was certainly a great divergity in trade and trade policies around the periphery. Before we explore that diversity and its correlation with performance, however, a brief digression is in order. Ideally, we would like to construct national indices of protection and test the hypothesis that countries with less protection converged more rapidly on the core than those with more protection, ceteris paribus. Unfortunately, and as the recent debate between John Nye (1991) and Douglas Irwin (1993) illustrates, life is not so simple: an adequate measure of protection has been elusive since it raises a classic index number problem. The standard trade-weighted average tariff (which is what the ratio of import duties to total imports boils down to) illustrates the problem clearly enough: as the tariff on good $i$ increases, the weight on good $i$ declines; if the tariff is raised so high that imports are excluded, the weight drops to zero, and the tariff no longer contributes to the index. When protection largely takes the form of quotas or prohibitions, these measurement problems become even more severe.

Other attempts to measure the openness of national economies have been no more satisfactory. The ratio of trade to GDP is clearly an unconvincing measure of openness since the equilibrium ratio might be low for some economies even under free trade. In response to this critique, Edward Leamer 
and others have developed a measure of trade openness based on a HeckscherOhlin empirical trade model. ${ }^{25}$ If trade patterns for a country do not conform with the predictions of the model, this is taken as evidence of protection. We will report estimates of protection based on this methodology for 1913, but accept the criticism that this index of protection may be flawed: after all, the model may not adequately describe international trade patterns. ${ }^{26}$

We take an eclectic approach in what follows. Firgt, we summarize what ig known about the evolution of trade policy in our seven countries. We next provide a brief synthesis of the trade policy literature as it applies to the European periphery. Finally, we report estimates of the impact of international commodity market integration in Sweden and Ireland, and use these to speculate about what globalization and protection implied for the rest of the periphery.

The Evolution of Trade Policies around the European Periphery

The evolution of European trade policies between 1860 and 1913 is well known. 27 The Franco-British trade agreement of 1860 initiated a wave of commercial treaties involving all the main European powers. The inclusion of the most-favored-nation clause into these treaties ensured that concessions were rapidly generalized, and Europe moved rapidly towards free trade. The turning point came in the late 18708 and 1880 , when cheap New World and Rusgian grain flooded Europe. Real Britigh land rents fell by $55 \%$ between 1870 and 1913, and in earlier work we have estimated that the grain invasion

25 See Leamer (1988), or Edwards (1992) for an application.

26 James Anderson and Peter Neary (1994) have proposed yet another index of protection, the trade restrictiveness index (TRI). The TRI is defined as the uniform tariff which would have the same static welfare effect as the structure of tariffs and quotas actually in place. While the TRI makes theoretical sense, by definition it can only be measured within the context of a particular general equilibrium model; o'Rourke (forthcoming) shows that in the historical episode which engaged Nye and Irwin in debate, the TRI is extremely sensitive to the specification of the model used to evaluate it.

27 Bairoch (1989) provides an excellent introduction. 
accounted for almost all of this decline. ${ }^{28}$ The grain invasion put rents under pressure elsewhere in Europe too (O'Rourke, Taylor and Williamson, 1996) and a political reaction was inevitable in countries where landlords and farmers wielded enough power. The German turning point came in 1879, when Bismark's 'marriage of iron and rye' afforded protection to both agriculture and indugtry; in France, the protectionist breakthrough is typically taken to be the Meline tariff of 1892, although dutieg on wheat and other agricultural products had been increased in 1885 and 1887. Of the three major Western European powers, only Britain adhered to free trade principles.

The European periphery can be slotted into this picture of the industrial core relatively easily. Table 8 summarizes such information as we have concerning tariff levels: it includes our seven countries together with comparable data for France and Germany. ${ }^{29}$ These data come in several forms. First, there are Bairoch's (1989) estimates of tariffs on wheat. Second, there are several average tariffs, computed using a variety of weights, for both manufacturing and the economy as a whole. These were computed by the League of Nations in 1927, by H. Liepmann in his classic Tariff Levels and the Economic Unity of Europe, and by Bairoch himself. Third, we report the estimates of sectoral and overall protection calculated by Estevadeordal (1993). These represent the only application of Leamer' methodology to pre-1914 data. First Estevadeordal estimated a model predicting trade flows for eighteen countries in 1913.30 He then constructed two measures of 'openness' based on the difference between countries' predicted and actual trade intensity ratios. Table 8 indicates where individual countries ranked among Estevadeordal's eighteen nations in terms of their openness (the most open being ranked 1 , and

28 Erratum to O'Rourke and Williamson (1994).

29 British tariff levels were of course identical to those in Ireland.

30 Countries in the Estevadeordal sample were: Argentina, Australia, Austria-Hungary, Belgium, Canada, Denmark, Finland, France, Germany, Italy, Netherlands, Norway, Portugal, spain, Sweden, Switzerland, the United Kingdom, and the United States. 
the most protected being ranked 18). While acknowledging the problems associated with Leamer's methodology, we prefer Estevadeordal's figures to crude tariff averages.

Ireland, of course, was a part of the United Kingdom's customs union, and as such remained a free-trader throughout our period. This is clearly reflected in Table 8, which shows Ireland to be the most open country overall in our sample according to nearly all the measures available.

Sweden, on the other hand, conforms well with the continental model. Johan August Gripenstedt had already begun to liberalize the country's trade in the 1850s, and Sweden entered into the web of bilateral treaties signed in the aftermath of Cobden-Chevalier (Heckscher, 1954: 237-8). Faced with the invasion of New World grain, agricultural protection was adopted in 1888 following a vigorous debate pitting smaller, net grain-using farmers against the larger, net grain-producing land-owners (Heckscher, 1954: 257; Kuuse, 1971: 40-4). The latter were better represented politically than the former, and so won the argument. Small-holders were further hurt by increased industrial protection, introduced in 1892, but were at least partially compensated by duties on pigmeat (Heckscher, op. cit: 238 ; Kuuse, ibid.). Swedish tariff history during this period thus resembles that of Germany. The data confirm that Sweden was imposing moderately high tariffs on both agriculture and industry, although she appears to have been rather more open than Italy and the Iberians.

Denmark, as is well known, adhered to free trade in agriculture throughout the grain invasion, engaging in a radical structural adjustment in the process. Whether this Danish response was due to the size distribution of farms, a high degree of social cohesion, the German defeat of 1864, or other factors, remains a topic of considerable interest (Kindleberger, 1951). Table 8 also indicates that Denmark protected manufacturing to a greater extent than is often appreciated. Overall, however, the conventional wisdom appears to be borne out: Denmark was one of the most open countries around the European periphery, second only to Ireland; and it was clearly more open than Sweden. 
Comparing Norwegian with Swedish levels of protection is more complicated. The tariff data for the end of our period tell an ambiguous story. As a percentage of 'special total imports', import duties in 1909-13 were higher in Norway than in Sweden. While Bairoch estimateg that Norway'g wheat tariffg were lower than Sweden's, Estevadeordal'g meagures show Norway being less open than sweden in both agriculture and industry.

It seems likely, therefore, that Norway was less open than Sweden on the eve of World War I. But focusing on the end of the period masks most of the story. Norwegian export interests (shipping, timber and fishing) were politically powerful, and Norway lacked a strong Swedish-style agrarian aristocracy. Thus, Norway maintained free grain imports from 1870 to 1905 , while larger European states moved towards agricultural protection. It was only in 1895 that protectionist sentiment in Norway increased, and duties on machine imports and meat were introduced. There was a more significant shift towards protection in 1905, when modest tariffs on grains were imposed; tariffs on animal produce were higher, confirming the influence of smaller farmers in Norway. Yet, it would appear that over most of our period, Norway was less protectionist than sweden.

Italy is another country which conforms well with the continental model. A free trader in the wake of Unification, Italy introduced moderate tariffs in 1878, and rather more severe tariffs in 1887. The latter duties led to a trade war with France, which lasted until 1892. By 1913 Italy was one of the most highly protected economiea in Europe, at least according to Estevadeordal. Liberalization was both shorter and less dramatic in spain. Prohibitions were abolished in 1869 and replaced with tariffs of 30-35 percent; while the intention was to reduce these to 15 percent by 1881 , they were not reduced in 1875, and were actually increased in 1877. While some duties were reduced in 1882, 1892 saw a return to very severe protection for cotton textiles, iron and steel, and cereals. Finally, while Bairoch (1989) portrays Portuguese trade policy as being fairly liberal until the adoption of a strict protectionigt tariff in 1892 , Laing points to the average tariff evidence, 
which indicates that Portuguese manufacturing enjoyed tariff protection of more than 20 percent between 1843 and $1913 . .^{31}$ It is certainly clear from Table 8 that both Spain and Portugal were highly protected in 1913: in our sample, Iberia appears to be the region least open to trade on the eve of World War I.

\section{The Impact of Trade Policies: Historical Debates}

What effect did trade policies have on economic performance around the European periphery? The political economy literature on late 19th century European trade is vast, but it focuses on the core industrial countries while tending to ignore comparative assessments of the periphery; and it focuses on the causes of trade policies, rather than their consequences. 32 obvious and notable exceptions include Paul Bairoch's (1976b) monumental book on the subject, and Berend and Ranki's (1980, 1982) work on the European periphery. As is well known, Bairoch is a pessimist regarding the impact of free trade in 19 th century Europe. His figures show aggregate growth on the continent slowing during the free trade era while accelerating during the oucceeding protectionist phase up to World War I.33 Moreover, Bairoch thought the free trade era was associated with international divergence, while the protectionist phase was associated with convergence. ${ }^{34}$ The more recent

31 "Portugal wag never a free trade country" (Lains 1992: 50). According to Lains, this fact can be explained both by the importance of tariff revenueg in the government's budget, and by pressure from industrialists and farmers.

32 The key statement in literature remains Kindleberger (1951); more recent contributions, by political scientists, include Mckeown (1983), Rogowski (1989) and Verdier (1994).

33 For an English-language summary of the argument, see Bairoch (1972).

34 Bairoch (1976b: 287-95); Bairoch (1972: 224-26). Capie (1982, 1994) takes isgue with Bairoch's conclusions, arguing that protection was not as high as is commonly thought in the late 19th century, and that in any case protection had little or no effect on economic performance. To establish the former point, Capie shows that in several cases, effective protection rates were much lower than nominal rates; to establish the latter point, he regresses growth rates against average nominal tariffs, and finds no significant relationship. 
evidence in section 2 suggests the contrary: while there was convergence throughout the period 1870-1914, it was far more dramatic prior to the mid 1890 s than after. In any case, Bairoch is invoking post hoc ergo propter hoc logic. Documenting trends in GDP per worker and real wages is not enough; we need some sense of the size of the price shocks associated with trade policy during this period, and we need economic models which can assess the impact of those price shocks on living standards in different countries.

According to Berend and Ranki (1980), international commodity market integration benefitted Scandinavia and (in a less central way) Italy; it was much less helpful to Spain, and no help at all to Portugal. The impact of foreign trade on the periphery thus varied enormously:

"the losses or gains sustained in the course of trade did not simply follow from a country's central or peripheral position, but were the consequences of the given country's particular production and export activity" (Berend and Ranki 1980: 550). Berend and Ranki follow the staples historians in pointing to the different linkages associated with, say, Swedish exports of iron ore and Greek exports of raisins. They also appeal to the ability of different countries to respond to price shocks, a response conditioned by a host of geographical, political, economic and cultural factors.

If the comparative literature on the impact of foreign trade and protection is sparse, there has been no shortage of individual country studies on the subject. ${ }^{35}$ Exports grew particularly rapidly in Scandinavia, and scholars there have long stressed the importance of export demand in explaining their own countries' success. For example, speaking of the Swedish 'break-through period' of 1850-1885, Fridlizius claims that

"the exports, new to Sweden, were an obvious condition for the industrial expansion, which began there during the later part of the 19th century ... Through the new export contacts with foreign countries,

35 Lains' (1992) dissertation on Portugal does include an extensive comparative discussion of trade elsewhere in Europe, and particularly in scandinavia. 
the knowledge of new techniques and industrial organization entered into the Swedish economic and industrial life ... The trade ... was not only the 'engine of growth'; it was also ... a means by which an intensive economic development spread from a centre to outlying parts of the world" (Fridlizius, 1963: 7-8).

Hodne (1973) points to a major role for foreign trade in explaining late 19th century Norwegian growth, while Jörberg (1970) does the same for Scandinavia as a whole. In reaction to these views, others have argued that domestic factors were more important than external factors in accounting for economic growth. ${ }^{36}$

Ireland was a member of the United Kingdom throughout the 19th century, and was thus exposed to the same free trade influences as Britain. Not surprisingly, nationalist Irish writers took a dim view of the effects of free trade on the country, arguing that economic union with Britain had condemned Ireland to deindugtrialization before the Famine. The Repeal of the Corn Laws was viewed as "another calculated aid" (0'Brien 1921: 197) to further depopulation, leading farmers to switch from labor-intensive tillage to landintensive pasture: "The Irishman, banished by the sheep and the ox, reappears on the other side of the ocean as a Fenian" (Marx 1977: 870). Late 19th century globalization was thus viewed in a uniformly pessimistic light by Irish nationalists; indeed, the term Sinn Fein, meaning ourselves, has its origins as a protectionist slogan.

The Italian debate on trade and protection in the late 19th century has largely taken its cue from Alexander Gerschenkron, who argued that the Italian tariff, protecting grain, cotton textiles, and iron and steel, was "one of the obstacles in the road of the Italian industrialization" (Gerschenkron 1962: 80). As a "tender plant", Italian industry was ill-equipped to cope with "the rigors of a protectionist climate in agriculture" (p. 81); cotton textiles enjoyed only "a moderate rate of modern technological progress and accordingly relatively limited possibilities in a backward country on the European

36 For a survey of the debate, see Hodne (1994). 
continent" (ibid.); costly iron and steel inhibited the development of engineering (p. 82), a point picked up by Toniolo (1977), who finds that the latter industry enjoyed only a negligible effective rate of protection. Stefano Fenoaltea (1973, 1993) joins Gerschenkron in criticizing protection. While admitting that the tariff system had its "incoherencies", Vera Zamagni (1993: 115, citing Federico 1984), on the other hand, argues that Italy would have suffered an increased rate of rural depopulation had there not been agricultural protection.

Iberian historians have recently devoted considerable energy to refuting the claims of dependency theorists that globalization hurt the periphery in the late 19th century. Federico (1988, 1992) surveys the literature, and links it with similar debates in Italy and Turkey. For example, Prados (1988: 21011; 1994) shows that the Prebisch hypothesis of deteriorating peripheral terms of trade did not hold for late 19th century Spain, while Lains (1986) attacks the dependency literature in the Portuguese context. Both Lains (1992) and Fontoura and Valério (1994) argue that protection retarded Portugese growth. On balance, the conventional wisdom in Iberia appears to have converged on that elsewhere in Europe, with trade being seen as having generally had positive effects. However, there are echoes of Irish scepticism in recent Italian and spanish literature, as regards the impact of free trade on agricultural labor demand: Alonso (1993, cited in Prados and Tena 1994) and Federico (1984, cited in Zamagni 1993) argue that rural depopulation in Spain and Italy would have increased in the absence of agricultural protection. We are interested not only in the convergence of real GDP per worker, but in real wage convergence. While neoclassical theory predicts that free trade improves aggregate welfare, it is ambiguous about real wages; if the grain invasion into the periphery lowered the demand for labor enough to offset cost of living gains, it might actually have led to real wage declines. Might protection thus have boosted real wages in the periphery? 
When analyzing the distributional impact of the grain invasion, most authors implicitly rely on the sector-specific factor model. Agriculture produces food using land and labor; industry produces manufactures using capital and labor. Let food be the import good and manufactures the export good. When food prices decline, agricultural labor demand falls, and nominal wages decline; on the other hand, lower food prices imply a lower cost of living for workers. The net impact on real wages is therefore ambiguous. If food is a sufficiently important part of workers' budgets, and if industry is a sufficiently small employer, then real wages increase; otherwise, they decline.

In countries such as Britain, where only a small share of the labor force was in agriculture, one might surmise that the cost-of-living effect would have dominated the labor demand effect, and that cheap grain would have boosted real wages; whereas in peripheral countries, with much larger agricultural sectors, the labor demand effect might have dominated, with cheap grain lowering real wages. In that case, free trade in grain could have led to real wage and living standard divergence within Europe, rather than convergence. O'Rourke (1994) has shown that agricultural employment would have been substantially higher in Ireland had the Corn Laws not been repealed. Preliminary work also suggests that cheap grain did indeed reduce swedish and French real wages. 37

However, grain was not the only commodity which was traded in the late 19 th century, and cheap grain was not the only price shock to which freetrading Europeans had to respond. To estimate the total impact of globalization on the European periphery, we need to measure changing international price gaps for animal products, 'Mediterranean' agricultural products, primary commodities (such as iron ore and timber), manufactured

37 O'Rourke (ongoing). Cheap grain did, of course, raise real wages in Britain (Williamson 1990). 
goods, and grain itself.

We did precisely this for Britain, the United States and sweden in previous papers (O'Rourke and Williamson 1994, 1995, 1996). There was certainly trans-Atlantic commodity price convergence, and the classic example is offered by the grain market. Liverpool was, of course, the major port handling Britain's grain trade while Chicago was the city closest to America's grain producers, so it is the Liverpool-Chicago price gap that mattered most. Liverpool prices exceeded Chicago prices by 60.3 percent in the three years centered on 1870 while they exceeded Chicago prices by only 14.9 percent in the three years centered on 1912. Price convergence was also manifested by beef, pork, bacon, mutton, butter, bar iron, cotton textiles, coal, copper, hides, wool, tin, cotton and many other tradables.

Since we know that Anglo-American tradable prices converged, we need only document the evolution of Anglo-Swedish price gaps to say something about both Anglo-Swedish and American-Swedish factor price convergence. Easier said than done, but what we can say can be quickly summarized. The price gap for vegetable products (barley, oats, wheat, potatoes) fell from about 55 percent (higher in Britain) in 1870 to about 18 percent in 1910. The experience of animal products (beef, pork and butter) was similar, the price gap declining from about 40 percent (higher in Britain) in 1870 to almost zero in 1910. The forestry sector (hewn timber) also conforms to Heckscher-ohlin hunches, the price gap there falling from more than 145 percent in 1870 to a little over 70 percent in 1910. In contrast, the price gap between Britain and sweden in the home-market-oriented industries (wheat flour, cotton yarn) fell only modestly, perhapg reflecting the effects of riaing tariffs. The big surprise, however, lies with the export industries: we found absolutely no evidence of price convergence there over the full forty years!

What impact did this swedish commodity market integration into the global economy have on catch-up? As Table 9 indicates, when a Swedish CGE is used to estimate the effects of Anglo-Swedish price convergence, the results were hardly dramatic. Anglo-Swedish commodity price convergence served to 
raise Swedish wages by only 1.9 percent, accounting for only about 3 percent of the decline in the Anglo-Swedish wage gap. 38 us-Swedish commodity price convergence had a little bigger impact, although still small. Commodity price convergence between the US and Sweden increased Swedish real wages by 6.28 , and raised US real wages by $0.38,39$ accounting for a little less than onetenth of the Swedish catch-up on the US.

However, the really important point about these results is that while cheap grain on its own might have lowered swedish real wages, commodity price convergence in general increased swedish real wages. We suspect that what was true of Sweden was true of the rest of Scandinavia as well. From what we know about the trade policies of our three countries, Heckscher-Ohlin effects were probably larger in Norway than in Sweden, and a lot larger in Denmark. This is reflected in the entries for the two countries in Table 9.40

What about the rest of the European periphery? George Boyer, Timothy Hatton and Kevin O'Rourke (1994) constructed a model of the Irish economy for 1907-8. While the model was originally constructed in order to assess the impact of emigration on Irish living standards, it can also be used to calculate the impact of declining trans-Atlantic price gaps on the Irigh economy. We ask: what would Irish real wages have been in 1908 if transAtlantic price gaps had remained constant in the four decades after 1870 , rather than declining as they actually did? When these counterfactual price shocks are imposed on the Irish model, real Irish wages increase by 9.6 percent, implying that declining trang-Atlantic price gaps lowered Irigh real

38 Calculated from O'Rourke and Williamson (1995: Appendix Table 2.4), and the wages in Williamson (1995: Appendix Table A2.1), Great Britain revised. Again, the ghare of convergence explained is a bit lower than the figure given in O'Rourke and williamson (1995: Table 1), as the earlier paper uged three-year averages to calculate 1870 and 1910 real wages.

39 O'Rourke and Williamson (1995: Appendix Table 2.4); erratum to O'Rourke and Williamson (1994).

40 The Danish and Norwegian numbers are not always identical to the Swedish numbers, since the same increase in the domestic wage will imply different percentage changes in wage gaps for different countries. 
wages by 8.8 percent. ${ }^{41}$ Real wages in the United States would only have been a fraction lower in the absence of trans-Atlantic price convergence. Table 9 thus indicates that Heckscher-Ohlin forces actually increased the US-Irish wage gap; they did not contribute to US-Irigh convergence at all.

We have not estimated the evolution of Anglo-Irish price gaps in the late 19 th century, but suspect that commodity market integration across the Irish Sea led above all to an increase in Irish animal product prices, as rail and steamships helped Irish farmers meet the growing British urban demand for breakfast foods. To the extent that Irish animal husbandry was land-intensive, this may have further reduced the demand for labor in Ireland. To evaluate the hypothesis more carefully, we would need an Irish model which distinguished between tillage and pasture (the current version has only one agricultural gector); and we would need price information which is currently unavailable. Table 9 reflects our uncertainty.

The Mediterranean countries generate even more uncertainty. As before, we would like to distinguish between trans-Atlantic and intra-European commodity market integration. If the Irigh experience is any guide, then the trans-Atlantic effect, by lowering grain prices, may have been to lower Mediterranean wages. On the other hand, intra-European integration may have had the opposite effect, by increasing the output of labor-intensive Mediterranean products (such as olives and wine), and of labor-intensive industrial and mining activities in Italy and Spain. Table 9 thus suggests that, for the Mediterranean periphery, trans-Atlantic integration led to divergence, while intra-European integration led to convergence; but we admit that this is purely speculative.

Measuring commodity market integration in various parta of the European periphery, and calculating the impact of this integration on individual countries, should be a major research priority. But what we know so far (Table

41 This counterfactual implies that Irish agricultural prices would have been 21.4 percent higher than they actually were in 1908, while imported manufactured goods would have been 9.8 percent cheaper than they actually were. Calculated from the Erratum to 0 'Rourke and Williamson 1994. 
9) suggests that these forces did not play a consistent role in contributing to catch-up and falling behind around the periphery. While it made a significant contribution to Scandinavian real wage catch-up, the contribution was far more modest, and often negative, elsewhere.

\section{THE CHALIEHGE OF COMPARATIVE HISTORY}

Table 10 summarizes our initial efforts to isolate the sources of late 19th century real wage and living standard catch-up and fall back around the European periphery. The comparative higtory seems to offer an explicit agenda.

First, it suggests that it might be of some value to think a little less like an economist and a little more like an historian. That is, it would be a mistake to try to force that experience into one tidy explanation, whether it comes from the fertile mind of Abramovitz, Gerschenkron, Heckscher, Ohlin, Sandberg, Solow or Tortella. Consider:

* Bad schooling explains an an enormous share of the Iberian fall back, but it explains none of the Irish and Italian catch-up. Good schooling certainly helps explain some of the Scandinavian success, but is 15 percent (an upper bound) worth all the shouting? Oddly enough, the scandinavian schooling thesis seems to work best in Iberia.

* * The workings of international factor markets on capital deepening was profound everywhere around the periphery. Mass migrations and international capital flows together served to explain a third to a half of the spectacular Scandinavian catch-up on Britain. They served to explain all of the Irish and Italian catch-up. And their relatively small numbers served to explain an important part of Iberian failure. Iberian isolation was a factor in accounting for its late 19th century failure, but it was factor market isolation that mattered most. Oddly enough, comparative debates over performance around the periphery have said little about factor market integration. In particular, it has said little about the inability of some poor countries to exploit emigration 
while others exploited it so well. These questions warrant more attention.

* The libraries are full of debates over late 19 th century tariff policy and the questions: What were the implications of the policy choice between free trade and autarky? What were the implications of world commodity market integration induced by declining transport costs? Given the amount of ink spilt on the question, we were gurprised by the tentative answer emerging from Table 10. The figures are uniformly small! They are even small (or negative) in the presence of free trade, as in Denmark and Ireland. They are unlikely to have explained much more than 5 percent of scandinavian catch-up, and while autarky helps explain Iberian failure, we suspect that it doesn't explain much. These are striking inferences that warrant more attention.

Second, note that the regidual is missing in some parts of the periphery. The last column in Table 10 reports the residual after the first four columns are added up. The entries for scandinavia seem plausible: about half (40-60 percent) of the catch-up can be explained by globalization and schooling; technological mysteries must explain the other half. The entries, however, are zero for Ireland, Italy and Portugal. A zero implies that none of the Irish or Italian catch-up on Britain was due to higher rates of Irigh or Italian total factor productivity growth generated by some technological transfer from rich leader to poor follower. It also implies that none of the Portuguese fall back can be attributed to slower rates of Portuguese total factor productivity growth relative to Britain. If true, these are striking inferences that warrant more attention.

Third, since this paper is already very long, perhaps we can be forgiven for not making better use of the counterfactual. Ireland achieved catch-up without industrialization. Relatively high rates of industrialization have always been positively correlated with relatively high rates of economy-wide total factor productivity growth. Both may have been absent in Ireland: what would have happened if there had been no mass emigration? Is mass emigration 
inconsistent with relatively rapid industrialization? This connection needs to be explored farther. Mass migration explains all of Italian catch-up and bad schooling explains all of Portuguese fall back. What would happen to these two inferences if both countries had experienced those big scandinavian residuals in Table 10? Mass emigration from Spain was small. What would have happened had Spanish emigration rates been like those in Italy? These questions imply that each "source" in Table 10 really cannot be treated independently of the others. Their connections warrant more attention.

Fourth, our tour around the periphery excluded eastern Europe, southeastern Europe and the eastern Mediterranean Basin. Is there reason to believe that the sources of convergence or divergence were different there? 
Table 1

Who is in Our European Periphy Sample?

\begin{tabular}{ccc}
\hline & (1) & (2) \\
Country & Real Wage Per Urban & Real GDP Per Head \\
Worker, 1870 (GB 1905=100) 1870 (1990 US\$)
\end{tabular}

The European Periphery

$\begin{array}{lrrrr}\text { Austria } & \text { na } & \text { (na) } & 1847 & (101) \\ \text { Denmark } & 36 & (80) & 1836 & (101) \\ \text { Finland } & \text { na } & (\text { na) } & 1095 & (60) \\ \text { Ireland } & 49 & (109) & \text { na } & (\text { na) } \\ \text { Italy } & 26 & (58) & 1568 & (86) \\ \text { Norway } & 28 & (62) & 1229 & (67) \\ \text { Portugal } & 32 & (71) & 793 & (43) \\ \text { Spain } & 51 & (113) & 1338 & (76) \\ \text { Sweden } & 28 & (62) & 1596 & (87) \\ & & & & \\ \text { Average } & 36 & (80) & 1419 & (78)\end{array}$

The European Industrial core

$\begin{array}{lrrrr}\text { Belgium } & 60 & (133) & 2572 & (141) \\ \text { France } & 50 & (111) & 1935 & (106) \\ \text { Germany } & 58 & (129) & 1619 & (89) \\ \text { Great Britain } & 67 & (147) & 315 & (171) \\ \text { The Netherlands } & 52 & (116) & 2490 & (136) \\ \text { Switzerland } & \text { na } & (\text { na) } & 2476 & (136) \\ \text { Average } & 57 & (127) & 2368 & (130) \\ & & & & \\ & 45 & (100) & 1826 & (100)\end{array}$

Notes and Sources: Col. (1) from Williamson (1995, Table A2.1, p. 178, GB revised); col. (2) from Prados, et. al (1993, Table 2, p.5) 
Table 2

Relative Economic Performance of the European Periphery

in the Late 19th Century:Growth per annum (8)

\begin{tabular}{|c|c|c|c|c|}
\hline Country & $\begin{array}{c}\text { Real Wage } \\
\text { Per } \\
\text { Urban Worker } \\
1870-1913\end{array}$ & $\begin{array}{c}(2) \\
\text { Wage-Rental } \\
\text { Ratio } \\
1870-1910\end{array}$ & $\begin{array}{c}(3) \\
\text { Real GNP } \\
\text { Per Capita } \\
1870-1913\end{array}$ & $\begin{array}{c}(4) \\
\text { Real GDP } \\
\text { Per } \\
\text { Worker-Hour } \\
1870-1913\end{array}$ \\
\hline \multicolumn{5}{|c|}{ The European Periphery } \\
\hline $\begin{array}{l}\text { Denmark } \\
\text { Finland } \\
\text { Norway } \\
\text { Sweden }\end{array}$ & $\begin{array}{l}2.41 \\
\text { na } \\
2.46 \\
2.92\end{array}$ & $\begin{array}{c}2.85 \\
\text { na } \\
\text { na } \\
2.45\end{array}$ & $\begin{array}{l}2.19 \\
1.19 \\
1.35 \\
2.39\end{array}$ & $\begin{array}{l}1.90 \\
1.80 \\
1.65 \\
1.74\end{array}$ \\
\hline Scandinavia & 2.60 & 2.65 & 1.78 & 1.77 \\
\hline $\begin{array}{l}\text { Italy } \\
\text { Portugal } \\
\text { Spain }\end{array}$ & $\begin{array}{l}1.71 \\
0.65 \\
0.01\end{array}$ & $\begin{array}{l}\text { na } \\
\text { na } \\
-1.04\end{array}$ & $\begin{array}{l}0.81 \\
0.18 \\
0.25\end{array}$ & $\begin{array}{l}1.33 \\
1.10 \\
1.52\end{array}$ \\
\hline $\begin{array}{l}\text { Mediterranean Basin } \\
\text { with Italy } \\
\text { without Italy }\end{array}$ & $\begin{array}{l}0.79 \\
0.33\end{array}$ & $\begin{array}{l}-1.04 \\
-1.04\end{array}$ & $\begin{array}{l}0.41 \\
0.22\end{array}$ & $\begin{array}{l}1.32 \\
1.31\end{array}$ \\
\hline $\begin{array}{l}\text { Austria } \\
\text { Ireland }\end{array}$ & $\begin{array}{c}\text { na } \\
1.39\end{array}$ & $\begin{array}{c}\text { na } \\
4.39\end{array}$ & $\underset{\text { na }}{1.15}$ & $\begin{array}{c}1.76 \\
\text { na }\end{array}$ \\
\hline Other Periphery & 1.39 & 4.39 & 1.15 & 1.76 \\
\hline Periphery & 1.65 & 2.16 & 1.19 & 1.60 \\
\hline \multicolumn{5}{|c|}{ The European Industrial core } \\
\hline $\begin{array}{l}\text { Belgium } \\
\text { France } \\
\text { Germany } \\
\text { Great Britain } \\
\text { The Netherlands } \\
\text { Switzerland }\end{array}$ & $\begin{array}{l}1.04 \\
0.65 \\
1.05 \\
0.89 \\
0.75 \\
\text { na }\end{array}$ & $\begin{array}{c}\text { na } \\
1.80 \\
0.87 \\
2.54 \\
\text { na } \\
\text { na }\end{array}$ & $\begin{array}{l}1.05 \\
1.06 \\
1.30 \\
1.00 \\
0.93 \\
1.32\end{array}$ & $\begin{array}{l}1.24 \\
1.58 \\
1.88 \\
1.23 \\
1.34 \\
1.46\end{array}$ \\
\hline Industrial core & 0.88 & 1.74 & 1.11 & 1.46 \\
\hline Europe & 1.33 & 1.98 & 1.16 & 1.54 \\
\hline \multicolumn{5}{|c|}{ The New World } \\
\hline $\begin{array}{l}\text { Argentina } \\
\text { Australia } \\
\text { Canada } \\
\text { USA }\end{array}$ & $\begin{array}{l}0.94 \\
0.01 \\
1.84 \\
0.90\end{array}$ & $\begin{array}{l}-4.06 \\
-3.30 \\
\text { na } \\
-1.72\end{array}$ & $\begin{array}{l}\text { na } \\
\text { na } \\
\text { na } \\
\text { na }\end{array}$ & $\begin{array}{l}\text { na } \\
1.08 \\
2.31 \\
1.93\end{array}$ \\
\hline New World & 0.92 & -3.03 & na & 1.77 \\
\hline
\end{tabular}

Notes and Sources. All averages are unweighted. Col. (1): real wage rate for unskilled urban workers, from Williamson (1995, Table A2.1, Great Britain reviged). Col. (2): ratio of Williamson's wage to land values per unit of 
farmland, from O'Rourke, Taylor and Williamson (1993, Table 3). Col. (3): gross national product in constant prices, per capita, from Bairoch (1976, Table 6). Col. (4): gross domestic product in constant prices, per workerhour, from Maddison (1991, Table C.11 and 1994, Table 2-1), except for Italy, Portugal and Spain which based on Bardini, Carerras and Lains (1995, Table 1), and the assumption that worker-hours per capita evolved the same way in Iberia as in Italy. 
Table 3

Unconditional Convergence Regressions for the Late 19th Century

\begin{tabular}{|c|c|c|c|c|}
\hline Sample & $\begin{array}{l}\hat{\beta} \text { on } \log \\
1870 \text { value }\end{array}$ & $\mathbf{R}^{2}$ & $N$ & $\lambda$ \\
\hline $\begin{array}{l}\text { [1] 1870-1913, real wage } \\
\text { Figure } 1\end{array}$ & $\begin{array}{l}-0.390 \\
(2.290)\end{array}$ & 0.27 & 16 & 0.011 \\
\hline $\begin{array}{l}\text { [2] 1870-1913, GDP per } \\
\text { worker }\end{array}$ & $\begin{array}{l}-0.025 \\
(0.255)\end{array}$ & 0.01 & 14 & 0.001 \\
\hline $\begin{array}{l}\text { [3] 1870-1913, GNP per } \\
\text { capita }\end{array}$ & $\begin{array}{l}-0.126 \\
(0.398)\end{array}$ & 0.16 & 11 & 0.003 \\
\hline
\end{tabular}

Source: See text. The Maddison GDP per worker sample ( $N=14)$ excludes Austria, Finland and Switzerland; it includes everything in the williamson real wage sample $(N=16)$ except Argentina and Ireland. From O'Rourke and williamson (1995, Table 2). 
Table 4

School Enrollment and Literacy Rates in the

18708 to 18908

\begin{tabular}{cccc} 
& $(1)$ & $(2)$ & $(3)$ \\
Country & O'Rourke-Williamson & Prados et al. \\
& Enrollment & Literacy & Enroliment \\
Rate & Rate & Rate \\
& Estimates & Estimates & Estimates \\
\hline
\end{tabular}

The European Periphery

\begin{tabular}{llll} 
Denmark & 0.70 & 0.99 & 0.51 \\
Finland & 0.10 & 0.89 & 0.15 \\
Norway & 0.64 & 0.98 & 0.47 \\
Sweden & 0.65 & 0.98 & 0.48 \\
Scandinavian Average & & & \\
with Finland & 0.52 & 0.96 & 0.40 \\
without Finland & 0.66 & 0.98 & 0.49 \\
Italy & 0.37 & 0.47 & 0.26 \\
$\begin{array}{l}\text { Portugal } \\
\text { Spain }\end{array}$ & 0.23 & 0.38 & 0.16 \\
Mediterranean Basin & 0.46 & 0.42 & 0.32 \\
with Italy & & & \\
without Italy & 0.35 & 0.42 & 0.25 \\
Austria & 0.35 & 0.40 & 0.24 \\
Ireland & 0.59 & 0.66 & 0.42 \\
Other Periphery & 0.45 & 0.91 & $\mathrm{n.a.}$ \\
Periphery & 0.52 & 0.79 & 0.42 \\
\hline
\end{tabular}

The Europen Industrial core

$\begin{array}{llll}\text { Belgium } & 0.56 & 0.86 & 0.41 \\ \text { France } & 0.80 & 0.96 & 0.55 \\ \text { Germany } & 0.73 & 0.97 & 0.51 \\ \text { Great Britain } & 0.53 & 0.96 & 0.40 \\ \text { The Netherlands } & 0.65 & 0.97 & 0.47 \\ \text { Switzerland } & 0.77 & 0.99 & 0.57 \\ \text { Industrial core } & 0.67 & 0.95 & 0.49 \\ \text { Europe } & 0.56 & 0.78 & 0.41\end{array}$

The New World

\begin{tabular}{llll} 
Argentina & 0.20 & 0.46 & n.a. \\
Australia & 0.84 & 0.97 & n.a. \\
Canada & 0.80 & 0.90 & n.a. \\
USA & 0.93 & 0.88 & n.a. \\
New World & & & \\
$\begin{array}{l}\text { With Argentina } \\
\text { without Argentina }\end{array}$ & 0.69 & 0.80 & n.a. \\
\hline
\end{tabular}

Notes and Sources: Based on O'Rourke and Williamson, 1995, Table 3. 
Table 5 (continued)

B.2 Share of growth gap between periphery and Britain explained by schooling:

$\begin{array}{lcc}\text { Denmark } & 15 & 3 \\ \text { Norway } & 10 & 2 \\ \text { Sweden } & 8 & 1 \\ \text { Ireland } & \text { none } & \text { none } \\ \text { Italy } & & \text { none } \\ \text { Portugal } & \text { none } & \text { all } \\ \text { Spain } & \text { all } & \text { all }\end{array}$

Noteg:

The following equation underlies the results given above in Panel B:

$$
(y-\bar{y})-\beta 1 *(w-\bar{w})=\beta 2 *(e-\bar{e})+e
$$

$\begin{array}{cc}\text { where } y & \text { = In } 1913 \text { wage - In } 1870 \text { wage } \\ W & =\text { In } 1870 \text { wage } \\ e & =\text { schooling variable (enroliment or literacy) }\end{array}$

B1 is the coefficient on In 1870 wage in the regression of wage growth on initial wage and enrollment literacy (Panel A.1 above) or (Panel A.2 above). B2 is the coefficient on the schooling variable in the same regression. The list of countries in each regression sample is given in panel $B$ with the country-specific results. The left side of the equation represents residual above or below average growth in wages net of the initial wage level, which is assumed to capture open economy effects. The right side is a calculation of the amount of wage growth due to above or below average levels of the education variable. By dividing the right side by the left side, we obtain the percentage of above or below average "residual" growth in wages attributable to above or below average levels of enrollment or literacy. 
The Impact of Mass Migration on Convergence Around the Periphery, 1870-1910

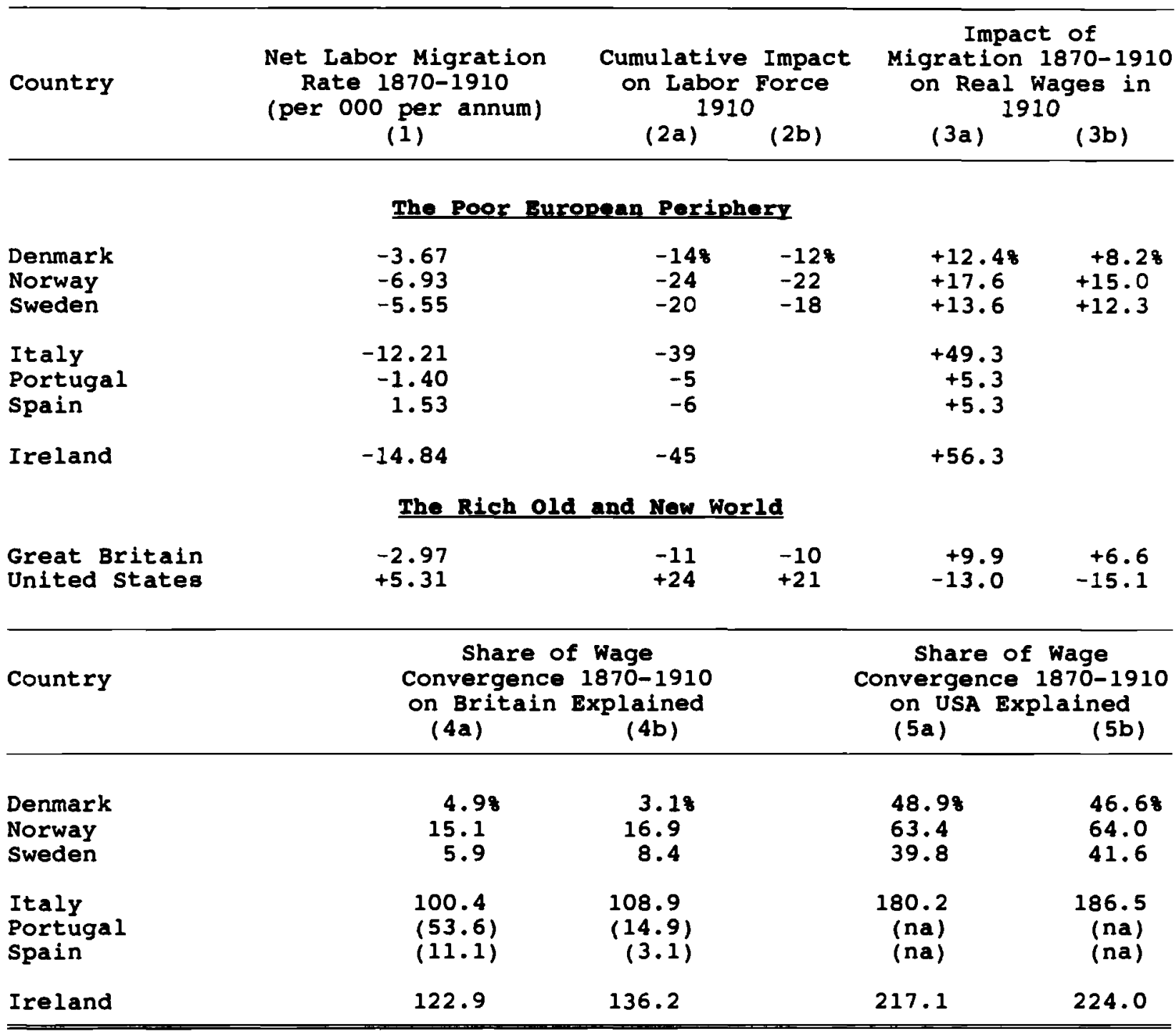

Notes and Sources: Cols. (1) and (2a) are from Taylor and Williamson (1995, Table 1, p.23). Col. (2b) is from O'Rourke and williamson (1996, section 4). Col. (3a) is from Taylor and williamson (1995, Table 4, p. 26), based on Col. (2a). Col. (3b) is from $O \cdot R o u r k e$ and williamson (1995, section 2; 1996, section 4). Cols. (4) and (5) take actual wage convergence 1870-1910 from williamson (1995, Table A2.1, Great Britain revised), while the migration impact is based on cols. (3a) and (3b). Since there are no CGE results for the Mediterraneans and Ireland, the entries for these countries in (4b) and (5b) are based on column (3a), and the British and US results in $(3 b)$. 
The Impact of International Capital Flows on Convergence Around the Periphery, 1870-1910

\begin{tabular}{ccc}
\hline & & Impact of \\
Country & $\begin{array}{c}\text { Cumulative Impact } \\
\text { on Capital stock } \\
(1)\end{array}$ & $\begin{array}{c}\text { Capital Flows, 1870-1910 } \\
\text { on Real Wages in } 1910\end{array}$ \\
(2)
\end{tabular}

The Poor European Periphery

$\begin{array}{lrr}\text { Denmark } & +16.38 & +8.28 \\ \text { Norway } & +17.48 & +8.88 \\ \text { Sweden } & +50.18 & +25.28 \\ & & 28 \\ \text { Italy } & \text { small negative? } & \text { small negative? } \\ \text { Portugal } & \text { small positive } & \text { small positive } \\ \text { Spain } & \text { small positive } & \text { small positive } \\ & \text { negative } & \text { negative }\end{array}$

The Rich old and New World

Great Britain

$-20.48$

$-7.38$

United states

$+0.38$

$+0.18$

$\begin{array}{ll}\text { Share of Wage } \\ \text { Country } & \text { Convergence 1870-1910 } \\ \text { on Britain Explained }\end{array}$

(3)
Share of Wage

Convergence 1870-1910

on USA Explained

(4)

\section{Denmark \\ Norway \\ Sweden \\ Italy \\ Portugal \\ spain}

Ireland

$$
\begin{aligned}
& 29.68 \\
& 34.28 \\
& 43.08
\end{aligned}
$$

positive positive positive

small positive

$16.2 \%$
19.68
34.28

small negative? omall positive small positive

negative

Notes and Sources: Cols. (1) and (2) are taken from the text. Cols. (3) and (4) are derived from Williamson (1995, Table A2.1, Great Britain revised) and column 2. Three of the Italian entries have question marks, indicating subgtantial uncertainty even as to the sign of effect. While the evidence for Ireland, Portugal and Spain is also weak, it is strong enough, we feel, to make unambiguous positive statements. 
Table $B$

European Tariffs 1875-1913

\begin{tabular}{|c|c|c|c|c|c|}
\hline \multirow[b]{2}{*}{ Country } & \multirow[b]{2}{*}{$\begin{array}{l}\text { Manufacturing } \\
1875\end{array}$} & \multicolumn{2}{|c|}{ a. Manufacturing } & \multirow[b]{2}{*}{$\begin{array}{l}\text { Manufacturing } \\
1913 \text { (3) (rank) }\end{array}$} & \multirow[b]{2}{*}{$\begin{array}{l}\text { Manufac } \\
1913 \quad 4 \\
\end{array}$} \\
\hline & & $\begin{array}{l}\text { Manufacturing } \\
1913 \text { (1) (percent) }\end{array}$ & $\begin{array}{l}\text { Manufacturing } \\
1913 \text { (2) (percent) }\end{array}$ & & \\
\hline Dermark & $15-20$ & 14 & n.a. & 16 & 14 \\
\hline Norway & $2-4$ & n.a. & n.a. & 8 & 8 \\
\hline Sweden & $3-5$ & 20 & 25 & 5 & 6 \\
\hline Italy & $8-10$ & 18 & 20 & 15 & 17 \\
\hline Portugal & $20-25$ & n.a. & n.a. & 14 & 13 \\
\hline Spain & $15-20$ & 41 & 34 & 18 & 18 \\
\hline Ireland & 0 & 0 & 0 & 4 & 5 \\
\hline France & $12-15$ & 20 & 21 & 12 & 12 \\
\hline \multirow[t]{2}{*}{ Germany } & $4-6$ & 13 & 13 & 6 & 3 \\
\hline & \multicolumn{5}{|c|}{ b. Agriculture } \\
\hline Country & $\begin{array}{l}\text { Wheat } \\
1913 \text { (percent) }\end{array}$ & $\begin{array}{l}\text { Agricul ture } \\
1913 \text { (1) (rank) }\end{array}$ & $\begin{array}{l}\text { Agricul ture } \\
1913 \text { (2) (rank) }\end{array}$ & & \\
\hline Dermark & 0 & 1 & 1 & & \\
\hline Norway & 4 & 16 & 13 & & \\
\hline Sweden & 28 & 7 & 8 & & \\
\hline Italy & 40 & 12 & 16 & & \\
\hline Portugal & Prohibitive & 18 & 18 & & \\
\hline Spain & 43 & 14 & 17 & & \\
\hline Ireland & 0 & 4 & 2 & & \\
\hline France & 38 & 10 & 12 & & \\
\hline \multirow[t]{2}{*}{ Germany } & 36 & 6 & 6 & & \\
\hline & \multicolumn{5}{|c|}{ c. Overall } \\
\hline Country & $\begin{array}{l}\text { Overall } \\
1913 \text { (1) (percent) }\end{array}$ & $\begin{array}{l}\text { Overall } \\
1913 \text { (2) (percent) }\end{array}$ & $\begin{array}{l}\text { Overall } \\
1913 \text { (3) (percent) }\end{array}$ & $\begin{array}{l}\text { Overall } \\
1913 \text { (4) (rank) }\end{array}$ & $\begin{array}{l}\text { Overall } \\
1913(5\end{array}$ \\
\hline Denmark & 5.8 & 9 & n.a. & 2 & 4 \\
\hline Norway & 11.4 & n.a. & n.a. & 11 & 12 \\
\hline Sweden & 9 & 16 & 28 & 7 & 7 \\
\hline Italy & 9.7 & 17 & 25 & 16 & 17 \\
\hline Portugal & 23.7 & n.a. & n.e. & 17 & 15 \\
\hline Spoin & 14.3 & 33 & 37 & 18 & 18 \\
\hline
\end{tabular}




\begin{tabular}{llllll} 
Ireland & 5.6 & 0 & 0 & 3 & 3 \\
France & 8.7 & 18 & 24 & 14 & 14 \\
Germany & 7.9 & 12 & 17 & 8 & 8 \\
\hline
\end{tabular}

\section{Notes:}

Manufacturing 1875: average levels of duties on manufactured products in 1875. Source: Bairoch (1989), Table 5, p. 42 .

Manufacturing 1913 (1): League of Nations estimate (Tariff Level Indices, Geneva: League of Nations 1927) as reported in Bairoch (1989), Table 9, p. 76.

Manufacturing 1913 (2): Liepmann estimate (Tariff Levelg and the Economic Unity of Europe, London: 1938) as reported in Bairoch (1989), Table 9, p. 76.

Manufacturing 1913 (3): rank among 18 countries (1=least protectionist, $18=$ most protectionist), based on the adjusted trade intensity ratios in Estevadeordal (1993), Table 3.7, p. 149.

Manufacturing 1913 (4): rank among 18 countries (1=least protectionist, 18=most protectionist), based on the openness measures in Estevadeordal (1993), Table 3.7, p. 150 .

Wheat 1913: levels of duties on wheat, calculated by Bairoch (1989), Table 9, p. 76 (based on information in British Board of Trade, Foreign Import Duties, London 1913.

Agriculture 1913 (1): rank among 18 countries (1=least protectionist, 18=most protectionist), based on the adjusted trade intensity ratios in Estevadeordal (1993), Table 3.7, p. 149.

Agriculture 1913 (2): rank among 18 countries (1=least protectionist, 18=most protectionist), based on the openness measures in Estevadeordal (1993), Table 3.7, p. 150 .

Overall 1913 (1): import duties as of special total imports (1909-1913), calculated by Bairoch (1989), Table 9, p. 76.

Overall 1913 (2): League of Nations estimate (Tariff Level Indices, Geneva: League of Nations 1927) as reported in Bairoch (1989), Table 9, p. 76.

Overall 1913 (3): Liepmann estimate (Tariff Levels and the Economic Unity of Europe, London: 1938) as reported in Bairoch (1989), Table 9, p. 76.

Overall 1913 (4): rank among 18 countries (1=least protectionist, 18=most protectionist), based on the adjusted trade intensity ratios in Estevadeordal (1993), Table 3.8, p. 151 .

Overall 1913 (5): rank among 18 countries (1=least protectionist, 18=most protectionist), based on the openness measures in Estevadeordal (1993), Table 3.8, p. 151 . 
The Impact of Commodity Market Integration on Convergence Around the Periphery, 1870-1910

\begin{tabular}{|c|c|c|}
\hline country & $\begin{array}{c}\text { Impact of Commodity } \\
\text { Market Integration, } \\
\text { trans-Atlantic, } \\
1870-1910 \text {, on Real } \\
\text { Wages in } 1910 \\
\text { (1) }\end{array}$ & $\begin{array}{c}\text { Impact of Commodity } \\
\text { Market Integration, } \\
\text { intra-European, } \\
1870-1910 \text {, on Real } \\
\text { Wages in } 1910 \\
\text { (2) }\end{array}$ \\
\hline $\begin{array}{l}\text { Denmark } \\
\text { Norway } \\
\text { Sweden }\end{array}$ & $\begin{array}{l}>6.28 \\
>6.28 \\
\\
6.28\end{array}$ & $\begin{array}{l}>1.98 \\
>1.98 \\
1.98\end{array}$ \\
\hline $\begin{array}{l}\text { Italy } \\
\text { Portugal } \\
\text { Spain }\end{array}$ & $\begin{array}{l}\text { negative? } \\
\text { negative? } \\
\text { negative? }\end{array}$ & $\begin{array}{l}\text { positive? } \\
\text { positive? } \\
\text { positive? }\end{array}$ \\
\hline Ireland & -8.88 & negative? \\
\hline country & $\begin{array}{c}\text { Share of Wage } \\
\text { Convergence } 1870-1910 \\
\text { on USA Explained } \\
\text { (3) }\end{array}$ & $\begin{array}{l}\text { Share of Wage } \\
\text { Convergence } 1870-1910 \\
\text { on Britain Explained } \\
\text { (4) }\end{array}$ \\
\hline $\begin{array}{l}\text { Denmark } \\
\text { Norway } \\
\text { Sweden }\end{array}$ & $\begin{array}{r}>12.08 \\
>13.68 \\
9.58\end{array}$ & $\begin{array}{l}>3.88 \\
>4.38 \\
\\
3.18\end{array}$ \\
\hline $\begin{array}{l}\text { Italy } \\
\text { Portugal } \\
\text { Spain }\end{array}$ & $\begin{array}{l}\text { negative? } \\
\text { negative? } \\
\text { negat ive? }\end{array}$ & $\begin{array}{l}\text { positive? } \\
\text { positive? } \\
\text { positive? }\end{array}$ \\
\hline Ireland & negative & negative? \\
\hline
\end{tabular}

Notes and Sources: see text for Cols. (1) and (2). Cols. (3) and (4) derived from columns (1) and (2), and Williamson (1995: Table A2.1, Great Britain revised). 
The Sources of Catch-Up and Fall Back Around The European Periphery, 1870-1910 (in percent)

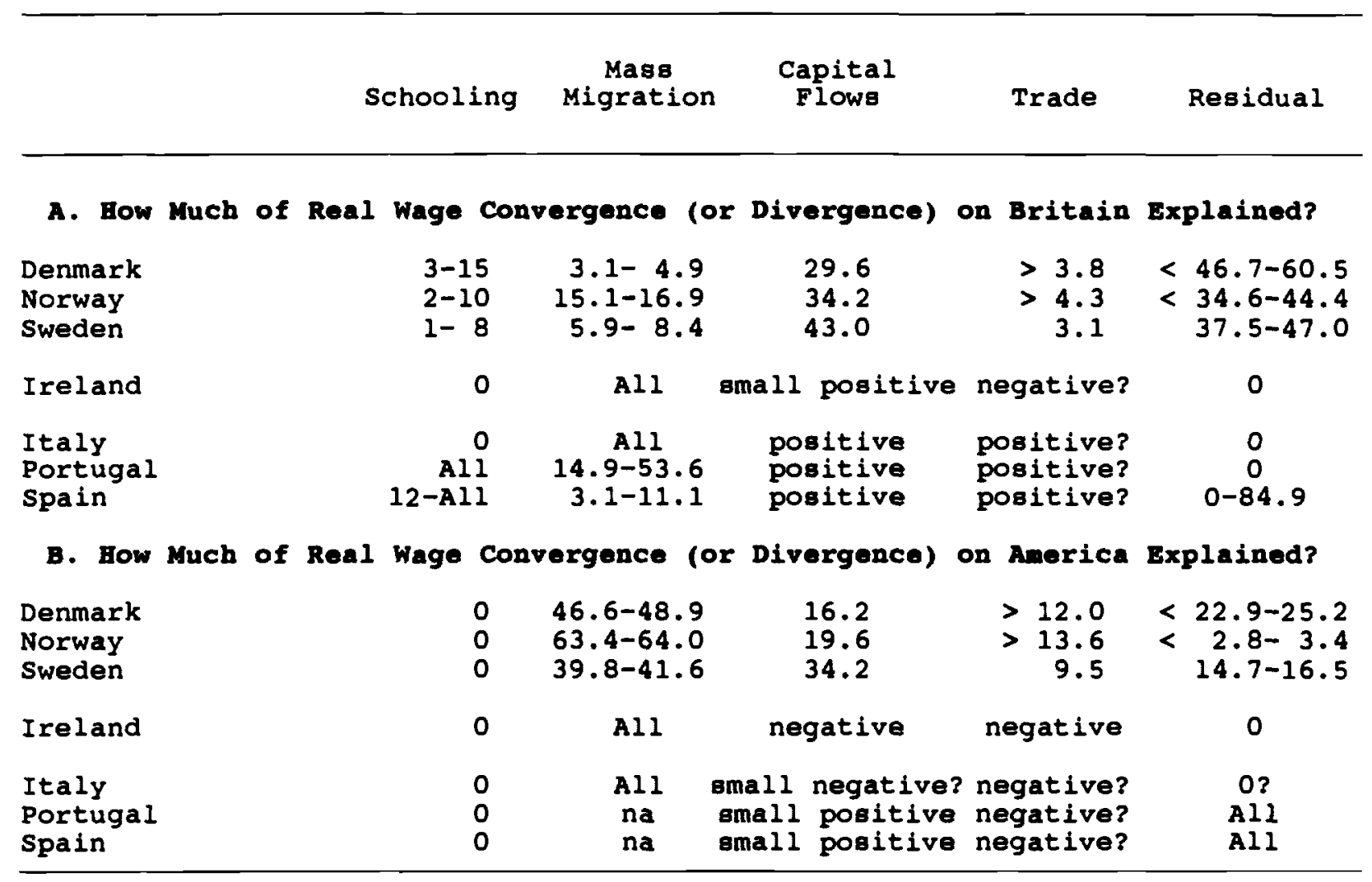

Sources: Taken from Tables 5 (Panel B-2), Table 6 (cols. 4a-5b), Table 7 (cols. 3-4), and Table 9 (cols. 3-4). 
Figure 1: "Unconditional" Real Wage Convergence, 1870-1913

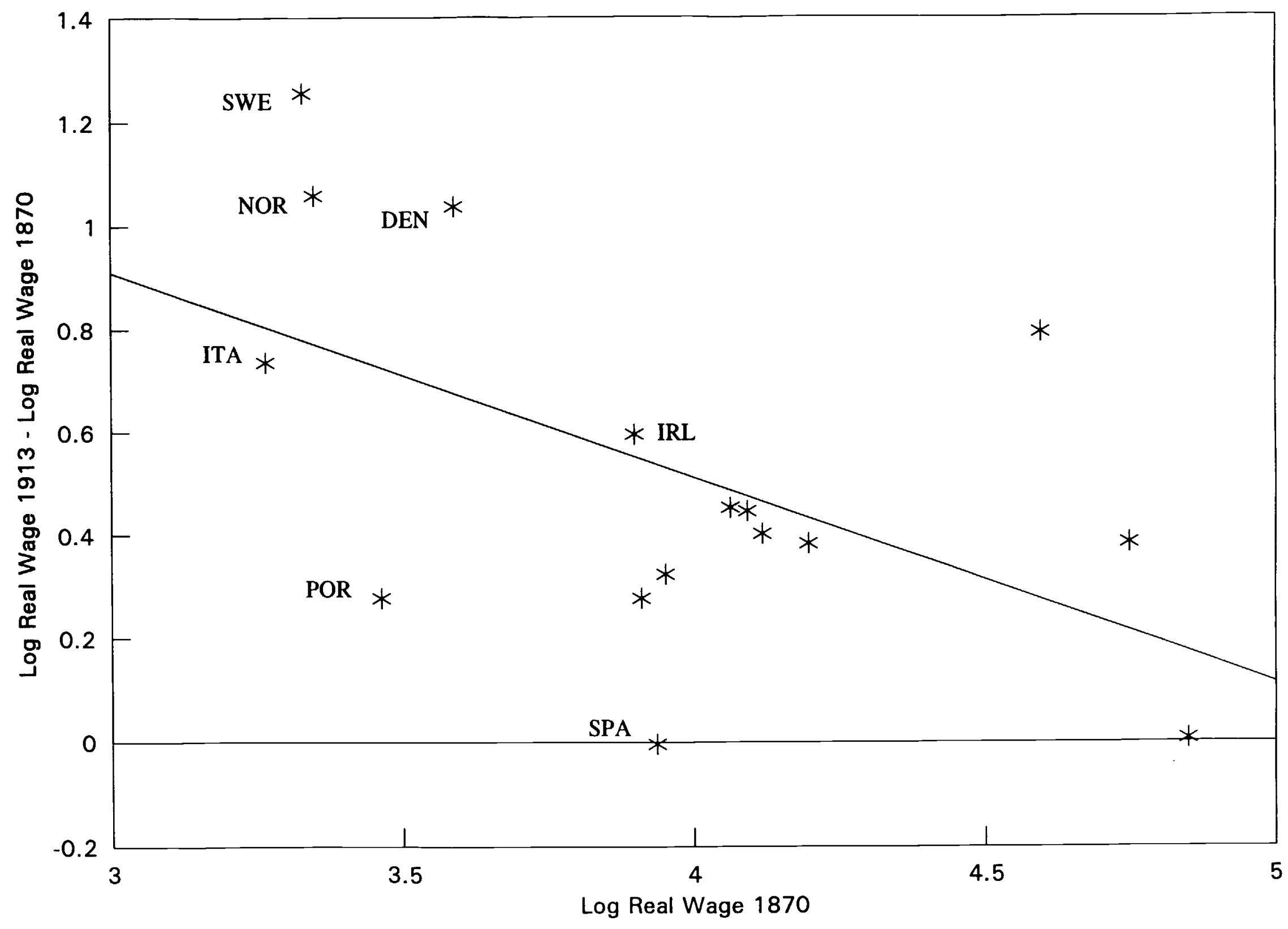




\section{REFERENCES}

M. Abramovitz [1986], "Catching Up, Forging Ahead and Falling Behind," Journal of Economic History 46, 2: 385-406.

B. S. Alongo [1993], Los Determinantes de la Emigración Eapañola (1880-1930), Ph.D. disgertation, European University Institute, Florence.

J. E. Anderson and J. P. Neary [1994], "Measuring the Restrictiveness of Trade Policy", The World Bank Economic Review 8, 2: 151-69.

P. Bairoch [1972], "Free Trade and European Economic Development in the 19th Century", European Econonic Review 3: 211-245.

P. Bairoch [1976a], "Europe'g Gross National Product: 1800-1975," Journal of European Economic History 5, 2: 273-340.

P. Bairoch [1976b], Commerce Exterieur et Développement Economique de l'Burope au XIX sizcle (Paris: Mouton).

P. Bairoch [1989], "European Trade Policy, 1815-1914", in P. Mathias and S. Pollard (eds.), The Cambridge Econonic History of Europe, Vol. 8 (Cambridge: Cambridge University Press).

C. Bardini, A. Carreras and P. Lains [1995], "The National Accounts for Italy, Spain and Portugal," scandinavian Economic Bistory Review XLIII: $115-46$.

R. J. Barro [1991], "Economic Growth in a Cross Section of Countries," Quarterly Journal of Economics 106, 2: 407-43.

R. J. Barro and X. Sala-i-Martin [1991], "Convergence Across states and Regions," Brookings Papers on Economic Activity 1: 107-82.

R. J. Barro and X. Sala-i-Martin [1992], "Convergence," Journal of Political Economy 100, 2: 223-51.

F. Barry [forthcoming], "Peripherality in Economic Geography and Modern Growth Theory: Evidence from Ireland's Adjustment to Free Trade", World Economy •

W. J. Baumol [1986], "Productivity Growth, Convergence and Welfare: What the Long-Run Data Show," American Economic Review 76, 5: 1072-85.

W. J. Baumol, S. A. Blackman and E. N. Wolff [1989], Productivity and Anerican Leadership: The Long View (Cambridge, Mass.: MIT Press). 
I. T. Berend and G. Ránki [1980], "Foreign Trade and the Industrialization of the European Periphery in the XIXth Century", Journal of European Economic History 9, 3: 539-584.

I. T. Berend and G. Ránki [1982], The European Poriphery and Industrialization 1780-1914 (Cambridge: Cambridge University Press).

G. R. Boyer, T.J. Hatton and K.H. O'Rourke [1994], "Emigration and economic growth in Ireland, 1850-1914", in T. J. Hatton and J.G. Williamson (eds.), International migration and world development (London: Rout ledge).

A. Broder [1976), "Les Investissements Etrangers en Espagne au XIXe Siècle: Methodologie et Quantification", Revue d'Histoire Econonique et sociale $54,1: 29-63$.

F. Capie [1982], "Tariff Protection and Economic Performance in the Nineteenth Century", in J. Black and I. A. Winters (eds.), Policy and Performance in International Trade (London: Macmillan).

F. Capie [1994], Tariffs and Growth: Some Insights from the World Economy, 1850-1940 (Manchester: Manchester University Press).

C. M. Cipolla [1969], Literacy and Development in the West (London: Penguin).

D. Davis [1992], Essays in the Theory of International Trade and Economic Growth, (Ph.D. dissertation, Columbia University).

R. Davis [1979], The Industrial Revolution and British Overseas Trade (Leicester: Leicester University Press).

J. B. Delong (1988), "Productivity Growth, Convergence and Welfare: Comment," American Economic Review 78: 1138-54.

S. Edwards [1992], "Trade Orientation, Distortions and Growth in Developing Countries", Journal of Development Econonics 39, 1: 31-57.

A. Estevadeordal [1993], Historical Essays on Comparative Advantage, 1913-38 (Ph.D. dissertation, Harvard University).

G. Federico [1984], "Commercio dei Cereali e dazio sul Grano in Italia (18631913): Una Analisi Quantitativa", Nuova Rivista storica 68: 46-108.

G. Federico [1988], "Commercio Estero e 'Periferie': Il Caso dei Paesi Mediterranei", Meridiana 4: 163-196. 
G. Federico [1992], "El Comercio Exterior de los Paises Mediterraneos en el Siglo XIX", in L. Prados de la Escosura and V. Zamagni (eds.), El Desarrollo Bconómico en la Europa del Sur: España e Italia en Perspectiva Histórica (Madrid: Alianza).

H. Feis [1930], Europe The World's Banker 1870-1914 (New Haven: Yale University Press).

S. Fenoaltea [1973], Riflessioni sull'Esperienza Industriale Italiana dal Risorgimento alla Prima Guerra Mondiale", in G. Toniolo (ed.), Lo Sviluppo Economico Italiano (Bari: Laterza).

S. Fenoaltea [1988], "International Resource Flows and Construction Movements in the Atlantic Economy: The Kuznets Cycle in Italy, 1861-1913", Journal of Economic History 48, 3: 605-637.

S. Fenoaltea [1993], "Politica Doganale, Sviluppo Industriale, Emigrazione: Verso una Riconsiderazione del Dazio sul Grano", Rivista di storia Economica 10: 65-77.

H. Flam and M. J. Flanders [1991], Beckscher-Ohlin Trade Theory (Cambridge, Mass.: MIT Press).

P. Fontoura and N. Valério [1994], "Protection, Foreign Trade and Economic Growth in Portugal 1840s-1980s: A Long Term View", paper presented to the Eleventh International Econonic History Congress, Milan.

G. Fridlizius [1963], "Sweden's Exports 1850-1960: A Study in Perspective", Economy and Bistory 6: 3-100.

A. Gerschenkron [1962], Economic Backwardness in Bistorical Perspective (Cambridge, Mass.: Harvard University Press).

G. Grossman and E. Helpman [1991], Innovation and Growth in the Global Economy (Cambridge, MA: MIT Presg).

S. A. Hansen [1970], Early Industrialization in Denmark (Copenhagen: Akademisk Forlag).

T. J. Hatton and J. G. Williamson [1994a], "International Migration 18501939: An Economic Survey," in T. J. Hatton and J. G. Williamson [eds.], Migration and the International Labor Market 1850-1939 (London: Rout ledge) . 
T. J. Hatton and J. G. Williamson [1994b], "Late-Comers to Mass Emigration: The Latin Experience," in T. J. Hatton and J. G. Williamson (eds.), Migration and the International Labor Market, 1850-1939 (London: Rout ledge).

T. J. Hatton and J. G. Williamson [1994C], "What Drove the Mass Migrations from Europe in the Late Nineteenth Century?" Population and Development Review 20: 533-59.

E. F. Heckscher [1954], An Economic History of Sweden (Cambridge, Mass.: Harvard University Press).

K.-G. Hildebrand [1978], "Labour and Capital in the Scandinavian Countries in the Nineteenth and Twentieth Centuries," in P. Mathias and M. M. Postan (eds.), The Cambridge Economic Bistory of Europe: Volume VII: The Industrial Economies: Capital, Labour and Enterprise: Part I (Cambridge: Cambridge University Press).

F. Hodne [1973], "Growth in a Dual Economy - The Norwegian Experience 18141914", Econony and History 16: 81-110.

F. Hodne [1994], "Export-Led growth or Export Specialization?", scandinavian Economic History Review 42, 3: 296-310.

D. A. Irwin (1993), "Free trade and protection in nineteenth-century Britain and France revisited: a comment on Nye", Journal of Economic History 53, $1: 146-152$.

H. C. Johansen [1985], Danish Historical statistics 1814-1980 (Copenhagen: Gyldendal).

L. Jörberg [1969], "Structural Change and Economic Growth: Sweden in the Nineteenth Century," in F. Crouzet, W. H. Chaloner and W. M. Stern (eds.), Essays in European Economic Bistory 1789-1914 (London: Edward Arnold).

L. Jörberg [1970], "The Industrial Revolution in the Nordic Countries," in C. M. Cipolla (ed.), The Emergence of Industrial societies: Part Two (London: Harvester Press).

K. A. Kennedy [1995], "The National Accounts for Ireland in the Nineteenth and Twentieth Centuries", Scandinavian Econonic History Review 43, 1: 101- 
114 .

C. P. Kindleberger [1951], "Group Behavior and International Trade," Journal of Political Economy 59, 1: 30-46.

P. R. Krugman and A. Venables [1990], "Integration and the competitiveness of peripheral industry", in C. Bliss and J. Braga de Macedo (eds.), Unity with Diversity in the European Community (Cambridge: Cambridge University Press).

P. R. Krugman and A. Venables [1995], "Globalization and the Inequality of Nations", MBER Working Paper 5098, Cambridge, MA (April).

J. Kuuse [1971], "Mechanization, Commercialization and the Protectionist Movement in Swedish Agriculture, 1860-1910," Scandinavian Economic History Review 19, 1: 23-44.

P. Lains [1986], "Exportaçoes Portuguesas, 1850-1913: A Tese de Dependência Revisitada", Analise Social 22: 381-419.

P. Lains [1992], Foreign Trade and Bconomic growth in the European Periphery: Portugal, 1851-1913 (Ph.D. disgertation, European University Institute, Florence).

E. E. Leamer [1988], "Measures of Openness", in R. E. Baldwin (ed.), Trade Policy Issues and Empirical Analysis (Chicago: University of Chicago Press).

H. Liepmann [1938], Tariff Levels and the Econonic Unity of Europe (London: Allen and Unwin).

R. Lucas [1990], "Why Doesn't Capital Flow from Rich to Poor Countries?", American Econonic Review 80, 2 : 92-96.

A. Maddison [1991], Dynamic rorces in Capitalist Development foxford: Oxford Univergity Press).

A. Maddison [1994], "Explaining the Economic Performance of Nations," in $W$. Baumol, R. Nelson and E. Wolff (eds.), Convergence of Productivity: Cross-National studies and Historical Evidence (New York: Oxford University Press).

N. G. Mankiw, D. Romer and D. N. Weil [1992], "A Contribution to the Empirics of Economic Growth," Quarterly Journal of Economics 107, 2: 407-37. 
I. Markussen [1990], "The Development of Writing Ability in the Nordic Countries in the Eighteenth and Nineteenth Centuries," scandinavian Journal of History 15, 1: 37-63.

K. Marx [1977], Capital Vol. 1 (New York: Vintage) .

E. Mata [1995], "Foreign Investments in the Portugese Economy from the Middle Nineteenth Century Till the First World War", paper presented to XV Encontro da Associação Portuguesa de Ristória Económica e Social, Evora.

R. Mundell [1957], "International Trade and Factor Mobility," American Economic Review 47: 321-335.

A. Nilsson and L. Pettersson [1990], "Some Hypotheses Regarding Education and Economic Growth in Sweden During the First Half of the 19th Century," in G. Tortella [ed.], Education and Economic Development since the Industrial Revolution [Valencia: Generalitat Valenciana].

A. Nilsson and L. Pettersson [1992], "Education, Knowledge, and Economic Transformation: The Case of Swedish Agriculture 1800-1870," Lund Papers in Economic History No. 13, Department of Economic History, Lund University.

C-E. Nuñez [1990], "Literacy and Economic Growth in Spain, 1860-1977," in G. Tortella [ed.], Education and Econonic Development since the Industrial Revolution [Valencia: Generalitat Valenciana] .

J. V. Nye [1991], "The Myth of Free-Trade Britain and Fortress France: Tariffs and Trade in the Nineteenth Century", Journal of Economic History 51, 1: $23-46$

G. O'Brien [1921], The Economic Bistory of Ireland from the Union to the Famine (London: Longmans, Green and Co.).

K. H. O'Rourke [1994], "The Repeal of the Corn Laws and Irish Emigration", Explorations in Economic History 31, 1: 120-138.

K. H. O'Rourke [1995], "Emigration and Living Standards in Ireland since the Famine", Journal of Population studies (forthcoming).

K. H. O'Rourke [forthcoming], "Measuring Protection: A Cautionary Tale", Journal of Development Economics.

K. H. O'Rourke [ongoing], "The European Grain Invasion, 1870-1913". 
K. H. O'Rourke, A. M. Taylor and J. G. Williamson [1993], "Land, Labor and the Wage-Rental Ratio: Factor Price Convergence in the Late Nineteenth Century," NBER Historical Paper No. 46, National Bureau of Economic Research, Cambridge, Mass. (March).

K. H. O'Rourke, A. M. Taylor and J. G. Williamson [1996], "Factor Price Convergence in the Late 19th Century", International Economic Review (forthcoming).

K. H. O'Rourke and J. G. Williamson [1994], "Late 19th Century Anglo-American Factor Price Convergence: Were Heckscher and Ohlin Right?," Journal of Economic History 54, 4: 1-25.

K. H. O'Rourke and J. G. Williamson [1995], "Open Economy Forces and Late 19th Century Swedish Catch-Up," Scandinavian Economic Bistory Review 43, 2 : 171-203.

K. H. O'Rourke and J. G. Williameon [1996], "Education, Globalization and Catch-Up: Scandinavia in the Swedish Mirror," scandinavian Economic History Review (forthcoming).

L. Prados de la Escosura [1988), De Imperio a Nación: Crecimiento y Atraso Económico en España (1780-1930) (Madrid: Alianza).

L. Prados de la Escosura [1994], "Terms of Trade and Bachwardness: Testing the Prebisch Doctrine for Spain and Britain During the Industrialization", Working Paper 94-46, Universidad Carlos III de Madrid (December).

L. Prados de la Escosura, T. Sanchez and J. Oliva [1993], "De Te Fabula Narratur? Growth, Structural Change and Convergence in Europe, 19th and 20th Centuries," Working Paper No. D-93009, Ministerio de Economia y Hacienda, Madrid (December).

L. Prados de la Escosura and A. Tena [1994], "Protectionism in Spain,18691930", paper presented to the Eleventh International Econonic History Congress, Milan.

J. Reis [1991], "The Gold Standard in Portugal, 1854-1891", paper presented to the Conference on the Gold standard in the Periphery, 1854-1939, Universidade Nova de Lisboa.

C. Riis and T. Thonstad [1989], "A Counterfactual study of Economic Impacts 
of Norwegian Emigration and Capital Imports," in I. Gordon and A. P. Thirlwall (eds.), European Factor Mobility: Trend and Consequences (London: Macmillan).

L.A. Rivera-Batiz and P.M. Romer [1991], "Economic Integration and Endogenous Growth", Quarterly Journal of Econonics CVI: 531-555.

R. Rogowski [1989], Commerce and Coalitions: How Trade Affects Domestic Political Arrangements (Princeton, NJ: Princeton University Press).

A. de O. Salazar [1916], O Ágio do Ouro: Sua Natureza - Suas causas, 1891-1915 (Coimbra: Imprensa da Universidade).

L. G. Sandberg [1979], "The Case of the Impoverished Sophigticate: Human Capital and Swedish Economic Growth before World War I," Journal of Economic History 39, 1: 225-41.

L. G. Sandberg [1982], "Ignorance, Poverty and Economic Backwardness in the Early Stages of European Industrialization," Journal of European Economic History 11, 3: 675-97.

P. M. Solar [1979], "The Agricultural Trade Statistics in the Irish Railway Commissioners' Report", Irish Econonic and Social History 6: 2440 .

N. Stokey [1991], "Human Capital, Product Quality, and Growth", Quarterly Journal of Economice CVI: 587-616.

A. M. Taylor and J. G. Williamson [1994], "Convergence in the Age of Mass Migration," MBER Working Paper No. 411 , National Bureau of Economic Research, Cambridge, Massachusetts (April).

A. M. Taylor and J. G. Williamson [1995], "Convergence in the Ageof Mass Migration," Harvard University, Cambridge, Mass. (revised, August). G. Toniolo [1977], "Effective Protection and Industrial Growth: The Case of Italian Engineering, 1898-1913", Journal of European Economic History 6: 659-673.

G. Tortella [1994a], "Patterns of Economic Retardation and Recovery in SouthWestern Europe in the Nineteenth and Twentieth Centuries," Economic History Review 47, 1: 1-21.

G. Tortella [1994b], El Desarrollo de la España Contemporanea: Historia 
Económica de los Siglos XIX y XX (Madrid: Alianza).

D. Verdier [1994], Democracy and International Trade: Britain, France, and the United states, 1860-1990 (Princeton, NJ: Princeton University Press). J.G. Williamson [1964], "Regional Inequality and the Process of National Development: a Description of the Patterns", Economic Development and Cultural Change 13: 3-45.

J. G. Williamson [1990], Coping with City Growth During the British Industrial Revolution, Cambridge: Cambridge University Press.

J. G. Williamson [1994], "Economic Convergence: Placing Post-Famine Ireland in Comparative Pergpective", Irish Economic and Social History 21: 1-27.

J. G. Williamson [1995], "The Evolution of Global Labor Markets Since 1850: Background Evidence and Hypotheses," Explorations in Bconomic Bistory $32,2: 1-54$.

J. G. Williamson [1996], "Globalization, Convergence and History, "Journal of Econonic History 56: forthcoming. Economic History Association 1995 presidential address.

A. Young [1991], "Learning by Doing and the Dynamic Effects of International Trade", Quarterly Journal of Economics CVI: 369-405.

V. Zamagni [1993], The Economic History of Italy 1860-1990 (Oxford: clarendon Press). 